This item was submitted to Loughborough's Research Repository by the author.

Items in Figshare are protected by copyright, with all rights reserved, unless otherwise indicated.

\title{
Environmental change over the last millennium recorded in two contrasting crater lakes in western Uganda, eastern Africa (Lakes Kasenda and Wandakara)
}

\section{PLEASE CITE THE PUBLISHED VERSION}

http://dx.doi.org/10.1016/j.quascirev.2010.11.011

\section{PUBLISHER}

(C) Elsevier Ltd.

\section{VERSION}

AM (Accepted Manuscript)

\section{LICENCE}

CC BY-NC-ND 4.0

\section{REPOSITORY RECORD}

Ryves, David B., Keely Mills, Ole Bennike, Klaus Peter Brodersen, Angela L. Lamb, Melanie J. Leng, James M. Russell, and Immaculate Ssemmanda. 2019. "Environmental Change over the Last Millennium Recorded in Two Contrasting Crater Lakes in Western Uganda, Eastern Africa (lakes Kasenda and Wandakara)". figshare. https://hdl.handle.net/2134/9394. 
This item was submitted to Loughborough's Institutional Repository (https://dspace.lboro.ac.uk/) by the author and is made available under the following Creative Commons Licence conditions.

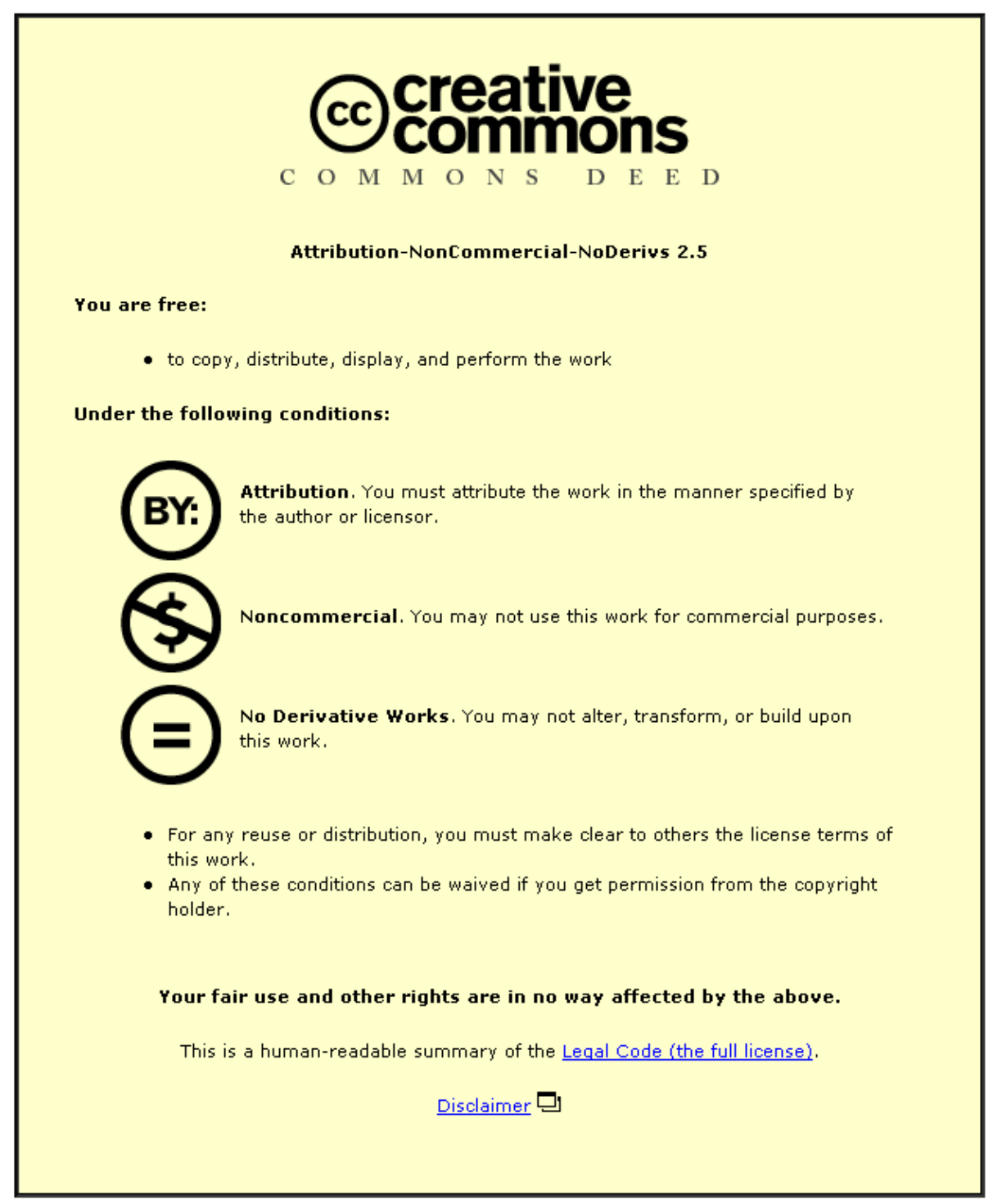

For the full text of this licence, please go to: http://creativecommons.org/licenses/by-nc-nd/2.5/ 


\section{Elsevier Editorial System(tm) for Quaternary Science Reviews Manuscript Draft}

\section{Manuscript Number: JQSR-D-09-00088R2}

Title: Environmental change over the last millennium recorded in two contrasting crater lakes in western Uganda, eastern Africa (Lakes Kasenda and Wandakara)

Article Type: Research and Review Paper

Corresponding Author: Dr David Ryves,

Corresponding Author's Institution: Loughborough University

First Author: David Ryves

Order of Authors: David Ryves; Keely Mills; Ole Bennike; Klaus P Brodersen; Angela L Lamb; Melanie J Leng; James M Russell; Immaculate Ssemmanda

Abstract: The last millennium is a key period for understanding environmental change in eastern Africa, as there is clear evidence of marked fluctuations in climate (effective moisture) that place modern concern with future climate change in a proper context, both in terms of environmental and societal impacts and responses. Here, we compare sediment records from two small, nearby, closed crater lakes in western Uganda (Lake Kasenda and Lake Wandakara), spanning the last 700 (Wandakara) and 1200 years (Kasenda) respectively. Multiproxy analyses of chemical sedimentary parameters (including $\mathrm{C} / \mathrm{N}$ ratios, ? $13 \mathrm{C}$ of bulk organic matter and $13 \mathrm{C}$ and 180 of authigenic carbonates) and biotic remains (diatoms, aquatic macrofossils, chironomids) suggest that Kasenda has been sensitive to climate over much of this period, and has shown substantial fluctuations in conductivity, while Wandakara has a more muted response, likely due to the increasing dominance of human activity as a driver of change within the lake and catchment over the length of our record. Evidence from both records, however, supports the idea that lake levels were low from AD 700 1000 AD, with increasing aridity from AD 1100 - 1600, with brief wet phases around AD 1000 and 1400. Wetter conditions are recorded in the 1700s, but drought returned by the end of the century and into the early 1800 s, becoming wetter again from the mid-1800s. Comparison with other records across eastern Africa suggests that while some events are widespread (e.g. aridity beginning AD 1100 ), at other times there is a more complex spatial signature (e.g. in the 1200 s to 1300 s, and from the 1400 s to 1600 s). This study highlights the important role of catchment-specific factors (e.g. lake morphometry, catchment size, and human impact) in modulating the sensitivity of proxies, and lake records, as indicators of environmental change, and potential hazards when regional inference is based on a single site or proxy. 


\section{Environmental change over the last millennium recorded in two contrasting crater lakes in western Uganda, eastern Africa (Lakes Kasenda and Wandakara)}

David B. Ryves ${ }^{\mathrm{a}^{*}}$, Keely Mills ${ }^{\mathrm{a}, 1}$, Ole Bennike ${ }^{\mathrm{b}}$, Klaus Peter Brodersen ${ }^{\mathrm{c}}$, Angela L. Lamb ${ }^{\mathrm{d}}$, Melanie J. Leng ${ }^{\mathrm{d}}$, James M. Russell ${ }^{\mathrm{e}}$, Immaculate Ssemmanda ${ }^{\mathrm{f}}$

${ }^{a}$ Centre for Hydrological and Ecosystem Science (CHES), Department of Geography, Loughborough University, Leics LE11 3TU, UK

${ }^{\mathrm{b}}$ Geological Survey of Denmark \& Greenland, Øster Voldgade 10, DK-1350 Copenhagen K, Denmark. Email: obe@geus.dk

${ }^{\mathrm{c}}$ Freshwater Biological Laboratory, Copenhagen University, Helsingørsgade 51, 3400 Hillerød, Denmark. Email: kpbrodersen@bio.ku.dk

${ }^{\mathrm{d}}$ NERC Isotope Geosciences Laboratory, British Geological Survey, Keyworth, Nottingham NG12 5GG, UK. Email: Melanie Leng [mjl@nigl.nerc.ac.uk]; Angela Lamb [alla@bgs.ac.uk]

${ }^{\mathrm{e}}$ Department of Geological Sciences, Brown University, Box 1846, Providence RI 02912, USA. Email: James_Russell@brown.edu

${ }^{\mathrm{f}}$ Department of Geology, Makerere University, P.O. Box 7062, Kampala, Uganda. Email: issemmanda@sci.mak.ac.ug

${ }^{1}$ Present address: School of Science and Engineering, The University of Ballarat, Victoria, 3350 Australia. Email: k.mills@ballarat.edu.au

Keywords: diatoms, chironomids, stable isotopes, macrofossils, Little Ice Age, eastern Africa, human impact, climate change

*Corresponding author: d.b.ryves@lboro.ac.uk; tel.: +44 1509228192 fax: +44 1509223930 


\begin{abstract}
The last millennium is a key period for understanding environmental change in eastern Africa, as there is clear evidence of marked fluctuations in climate (effective moisture) that place modern concern with future climate change in a proper context, both in terms of environmental and societal impacts and responses. Here, we compare sediment records from two small, nearby, closed crater lakes in western Uganda (Lake Kasenda and Lake Wandakara), spanning the last 700 (Wandakara) and 1200 years (Kasenda) respectively. Multiproxy analyses of chemical sedimentary parameters (including $\mathrm{C} / \mathrm{N}$ ratios, $\delta^{13} \mathrm{C}$ of bulk organic matter and $\delta^{13} \mathrm{C}$ and $\delta^{18} \mathrm{O}$ of authigenic carbonates) and biotic remains (diatoms, aquatic macrofossils, chironomids) suggest that Kasenda has been sensitive to climate over much of this period, and has shown substantial fluctuations in conductivity, while Wandakara has a more muted response, likely due to the increasing dominance of human activity as a driver of change within the lake and catchment over the length of our record. Evidence from both records, however, supports the idea that lake levels were low from $\sim \mathrm{AD} 700-1000 \mathrm{AD}$, with increasing aridity from AD 1100 - 1600, with brief wet phases around AD 1000 and 1400. Wetter conditions are recorded in the 1700s, but drought returned by the end of the century and into the early 1800s, becoming wetter again from the mid1800s. Comparison with other records across eastern Africa suggests that while some events are widespread (e.g. aridity beginning $\sim \mathrm{AD} 1100$ ), at other times there is a more complex spatial signature (e.g. in the 1200 s to 1300 s, and from the 1400 s to 1600 s). This study highlights the important role of catchment-specific factors (e.g. lake morphometry, catchment size, and human impact) in modulating the sensitivity of proxies, and lake records, as indicators of environmental change, and potential hazards when regional inference is based on a single site or proxy.
\end{abstract}




\section{Introduction}

Knowledge of past environments, especially climate, can be extremely relevant not only for providing insight into natural variability of Earth systems, but also to understand the socio-

political and ecological response of past societies (Haberle and David, 2004; Tinner et al., 2003) and provide new perspectives on the possible impacts of future change on modern societies (deMenocal, 2001). Recent research from key archaeological sites in western Uganda suggests that cultural and political transformations throughout the pre-colonial period were closely linked with fluctuations in the environment, and particularly in effective moisture, over the last 1000 years (Taylor et al., 2000).

Most palaeolimnological research in equatorial eastern Africa has been carried out on the large, open lakes in the region (e.g., Lakes Victoria, Edward and Albert), which, although sensitive to major impacts (e.g. regional climate change: Stager and Mayewski, 1997), may smooth out some of the inherent regional complexity by integrating responses over large areas, and, depending on their residence times, over longer timescales (Fritz, 2004). Recently, palaeolimnological studies from smaller lakes are yielding high resolution $\left(10^{0}-10^{2} \mathrm{yr}\right)$ records of environmental and climatic change (Bessems et al., 2008; Russell et al., 2007; Ssemmanda et al., 2005), often highlighting smaller-scale, shorter-term changes. Such studies can both complement, and challenge, the regional view afforded by palaeolimnological records of larger lakes.

In particular, a series of small crater lakes in western Uganda provides an opportunity to explore regional and local signals of environmental change in a variety of different hydrological settings. As many crater lakes lack a surface outflow, the simplest model of lake water balance is driven by precipitation $(\mathrm{P})$ and evapotranspiration $(\mathrm{E})$ in the catchment, assuming minimal impacts from groundwater flows. Under such conditions, lake salinity (inversely related to water volume, or lake level) can be used as a palaeoclimate proxy to infer past effective moisture (P-E). While natural systems are rarely so simple (Fritz, 2008), depending on the sensitivity of the particular proxy and lake system to a given climatic or hydrological perturbation, this approach can provide valuable insight into past environmental change. Both biological (e.g. diatoms and chironomids; Eggermont et al., 2006; Gasse et al., 1995) and geochemical proxies (e.g. stable isotopes of authigenic carbonates, Leng and Marshall, 2004) are sensitive to in-lake hydrological changes and can provide independent evidence of past water balance. Given differences in response rates and ranges between proxies, a multiproxy approach provides a powerful means to 
reconstruct past environments, while paired (or better still, multiple) lake studies should be carried out if the purpose is to identify and separate local (catchment-scale) from landscape or regional effects (Fritz, 2008; Street-Perrott et al., 2007).

Recent palaeolimnological work across eastern Africa suggests that the patterns of past climate change in the late Holocene are spatially complex (cf. Lamb et al., 2007b; Russell and Johnson, 2007; Stager et al., 2005; Verschuren et al., 2000). For example, questions remain over the spatial extent and synchroneity of climatic changes in eastern Africa and their relationships to events at higher latitudes, such as the extent of aridity in the $15^{\text {th }}-18^{\text {th }}$ centuries (coincident with the Little Ice Age; Ssemmanda et al., 2005; Russell et al., 2007). Research focused on short-term, regionally specific archives of natural climate variability (cf. Ssemmanda et al., 2005; Russell et al., 2007; Bessems et al., 2008; Mills, 2009; Russell et al., 2009) have shown that, while there is great potential for extracting high quality, high resolution archives from the smaller lakes in western Uganda which can address such issues, these archives remain underexploited.

Sediment sequences from two nearby, closed crater lakes (Lakes Kasenda and Wandakara, $\sim 12^{\circ} \mathrm{N}, 30^{\circ} \mathrm{E}$ ) span the last 700 (Wandakara) and 1200 years (Kasenda), and have provided a regional history of vegetation and catchment change (Ssemmanda et al., 2005). Here we present diatom, chironomid, aquatic macrofossil, stable isotopic $\left(\delta^{13} \mathrm{C}_{\text {org }}\right.$ from organic matter; $\delta^{13} \mathrm{C}_{\text {carb }}$ and $\delta^{18} \mathrm{O}_{\text {carb }}$ from authigenic carbonates) and $\mathrm{C} / \mathrm{N}$ records from these sequences to provide a multiproxy reconstruction of aquatic environmental changes over the last 1200 years, and set these in the context of late Holocene environmental change across eastern Africa.

\section{Study area and site description}

Lakes Kasenda and Wandakara are located within the Kasenda cluster of phreatomagmatic explosion craters in western Uganda, and form part of a series of crater (or maar) lakes associated with the western branch of the East African Rift System (Figures 1a and b). The rainfall in this region is seasonally bimodal (March-May, October-December), with the wet seasons being related to the passage of the Inter Tropical Convergence Zone (ITCZ) through the region. There is little variation in the diurnal and monthly temperatures (daily variation $10-15^{\circ} \mathrm{C}$, mean 
monthly maxima $24-27^{\circ} \mathrm{C}$; Atlas of Uganda, 1962; recent data available from the Ugandan Government Department of Meteorology; www.meteo-uganda.net/). The natural vegetation of the region is low-altitude montane forest (Langdale-Brown et al., 1964; Ssemmanda et al., 2005; Taylor et al., 1999), which, outside of the national parks, has been subjected to widespread clearance to make way for small-scale agriculture and banana plantations.

Lakes Kasenda $\left(0^{\circ} 26^{\prime} \mathrm{N}, 30^{\circ} 17^{\prime} \mathrm{E}, 1260 \mathrm{~m}\right.$ a.s.l) and Wandakara $\left(0^{\circ} 25^{\prime} \mathrm{N}, 30^{\circ} 16^{\prime} \mathrm{E}\right.$, 1170 m a.s.l) are two closed crater lakes, located close to the Kibale Forest National Park (Figure 1c). Lake Kasenda is a $0.13 \mathrm{~km}^{2}, 13 \mathrm{~m}$ deep, freshwater lake $\left(380 \mu \mathrm{S} \mathrm{cm}^{-1}\right)$ in a crater with a topographic catchment area of $c .2 \mathrm{~km}^{2}$. Lake Wandakara is $0.04 \mathrm{~km}^{2}$ and has a maximum depth of $12 \mathrm{~m}$, but a higher conductivity $\left(1269 \mu \mathrm{S} \mathrm{cm}^{-1}\right)$ and a smaller catchment area $\left(c .0 .13 \mathrm{~km}^{2}\right)$. The lakes differ in the extent of human impact within their catchment. Lake Kasenda lies within a privately owned estate, and agricultural development (pre-2001) has been limited allowing significant areas of natural forest to remain within the crater rim. The catchment of Lake Wandakara contains almost no original vegetation, and small-scale plantation agriculture occupies most of the steep crater slopes from the rim to the shore. Ssemmanda et al. (2005) provide a fuller description of the vegetation around both lakes.

\section{Methods}

\subsection{Coring, sampling, physical analyses and dating}

Sediment cores were collected from the deepest parts of Lakes Kasenda and Wandakara in July 2000. The uppermost, unconsolidated sediments, including the undisturbed sediment-water interface, were retrieved using a $9 \mathrm{~cm}$ diameter HON-Kajak gravity corer (Renberg, 1991) and extruded in the field (master Kajak lengths of $31 \mathrm{~cm}$ at Kasenda and $39 \mathrm{~cm}$ at Wandakara). Deeper, consolidated sediments were collected using a 1m long, $10 \mathrm{~cm}$ diameter Russian peat corer. Multiple Russian cores from two parallel drives (each consisting of two 1m-Russian core sections at both lakes) were taken to ensure overlap between adjacent core sections. Russian cores were wrapped in polythene immediately after collection, stored in core boxes and air freighted to Denmark where they were kept refrigerated at $4^{\circ} \mathrm{C}$ until subsampling. The cores from 
each lake were correlated by a combination of visual stratigraphy, organic matter (using loss-onignition, LOI; Dean, 1974) and magnetic susceptibility profiles, which provide clear markers across cores within each lake. Composite sequences for both lakes include correlated samples from several individual cores, totalling $158 \mathrm{~cm}$ at Kasenda and $223 \mathrm{~cm}$ at Wandakara. Stratigraphic sampling density (detailed in Section 3) differs between proxies but was highest for organic matter (every $1 \mathrm{~cm}$ for both lakes) and bulk magnetic susceptibility (every $0.5 \mathrm{~cm}$ at Kasenda and every $1 \mathrm{~cm}$ at Wandakara; Ssemmanda et al., 2005). Proxy sampling strategies coincided as far as possible so that analyses were performed on the same levels (from correlated cores as necessary). Individual samples for biotic and isotopic analyses integrate 1-5 years over the last 100 years at both sites, and typically 10 years (Wandakara) or 20 years (Kasenda) prior to this (5 to 10 years respectively for diatoms). In the lower core sections, this time averaging, and sampling interval, limits the temporal resolution possible for these proxies in earlier parts of both records.

The core sequences from Lakes Kasenda and Wandakara have been dated with a combination of ${ }^{210} \mathrm{~Pb},{ }^{137} \mathrm{Cs}$ (using the constant rate of supply model; Appleby, 2001) and AMS ${ }^{14} \mathrm{C}$ dates on paired terrestrial macrofossils from the base of each sequence. Further details of physical analyses, dating techniques, construction of age-depth curves and sedimentation rates for both lakes are provided by Ssemmanda et al. (2005). Additionally, piston cores taken at both lakes in 2001-2 (Bessems, 2007) provide further lithological and stratigraphical information which can be correlated to the sequences discussed here by physical analyses (e.g. organic and carbonate content, and bulk magnetic susceptibility; Bessems, 2007) and bulk $\delta^{13} \mathrm{C}_{\text {org }}$ analysis (Russell et al., 2009), which agree well between cores. For Kasenda, further dating control is provided by an AMS age determination on mixed terrestrial macrofossils (dated to AD 1425; Bessems, 2007), agreeing within the error range with our dating model for Kasenda and validating our chronology (Ssemmanda et al., 2005). The age model for Lake Wandakara has been refined by treating a low organic, high magnetic susceptibility minerogenic layer ( 109-121 $\mathrm{cm}$ in the sequence discussed here) as an essentially instantaneous deposit (Bessems, 2007). Nonetheless, given relatively sparse dating control beyond the ${ }^{210} \mathrm{~Pb}$ record of the last $\sim 120$ years, some caution with the age models should be exercised, although dating at the base of both sequences is considered secure (cf. Fig. 7). 


\subsection{Diatom analysis}

Samples for diatom analysis were prepared following the water bath method (Renberg, 1990) for 37 samples from each lake sequence, each of $1 \mathrm{~cm}$ thickness. At Kasenda, samples were analysed every $2 \mathrm{~cm}$ in the upper $10 \mathrm{~cm}$, and approximately every $4-5 \mathrm{~cm}$ thereafter; at Wandakara, every $2 \mathrm{~cm}$ in the upper $10 \mathrm{~cm}$, every $5 \mathrm{~cm}$ from $10-50 \mathrm{~cm}$, and every $8-10 \mathrm{~cm}$ thereafter. In both cases, additional samples were analysed at periods of key floristic change. Strewn slides were mounted in Naphrax, and at least 300 valves per sample were counted in transects under oilimmersion phase-contrast light microscopy (LM) at x1000 magnification. A variety of general (e.g. Germain, 1981; Krammer and Lange-Bertalot, 1986; Krammer and Lange-Bertalot, 1988; Krammer and Lange-Bertalot, 1991a; Krammer and Lange-Bertalot, 1991b) and regional floras (e.g. Cocquyt, 1998; Gasse, 1986) were consulted, and valves identified to species level, if possible. Digital recordings of both typical and problematical specimens were made during counting to aid taxonomy, and compared with images of African diatoms held in the European Diatom Database (EDDI). Diatom concentrations were estimated by adding a known number of inert microspheres to the samples (Battarbee and Kneen, 1982).

Species that appear to exhibit distinct size variation between samples were split into size fractions, but these were combined for transfer function modelling. A small Nitzschia common to both lakes, labelled Nitzschia aff. bacillum, was split into three size fractions (based on apical length: $<12 \mu \mathrm{m}, 12-24 \mu \mathrm{m}$ and $>24 \mu \mathrm{m}$ ), which appeared to represent a continuum differing only by size. Although subsequent discussion with C. Cocquyt (National Botanical Gardens, Belgium) suggests the $>24 \mu \mathrm{m}$ fraction fits the description for $N$. confinis Hust., as this taxon was always found with apparently identical, only smaller, forms, we choose to use the name Nitzschia aff. bacillum here and merge the counts for inference purposes as N. bacillum Hust..

Preservation of diatom assemblages was assessed by means of a simple fractional diatom dissolution index (F index; Ryves et al., 2001). This is the fraction of valves without visible signs of dissolution as a proportion of all valves counted during routine LM analysis. This ratio varies from 0 (all valves partly dissolved) to 1 (perfect preservation) and allows a more objective 
method of assessing and comparing dissolution amongst different assemblages (Ryves et al., 2006; Ryves et al., 2001).

\subsection{Chironomid analysis}

Samples at Wandakara were analysed every $2 \mathrm{~cm}$ in the upper $10 \mathrm{~cm}$, and then every $5 \mathrm{~cm}$ to 20 $\mathrm{cm}$, and every $\sim 10-15 \mathrm{~cm}$ thereafter (21 samples total). Before screening for chironomid head capsules, the samples were treated following the procedures of Hofmann, (1986), with deflocculation in hot $10 \% \mathrm{KOH}$, hydrochloric acid $(\mathrm{HCl})$ treatment and sieving through a $93 \mu \mathrm{m}$ mesh. Head capsules were sorted under a dissection microscope at x50 magnification, dehydrated in $96 \%$ and $99 \%$ ethanol, and mounted in Euparal ${ }^{\circledR}$. Identification primarily follows the eastern African regional classification of Verschuren, (1997), updated with Eggermont and Verschuren, (2004a) and Eggermont and Verschuren, (2004b) where appropriate. Subfossil remains of larval Diptera include both chironomids and chaoborids (two possible mosquito larvae headcapsules were also encountered at Wandakara). Subfossil head capsule concentrations in samples from Lake Kasenda were too low to permit reliable stratigraphic interpretations of the chironomid community; hence results are only presented here from Lake Wandakara. A first-order salinity inference was made applying weighted average optima from Eggermont et al. (2006, Appendix A) to fossil data, weighting by relative abundance but without deshrinking functions, which are not published. This approach is not meant to derive precise salinity inference but rather to allow trends in salinity over time to be inferred and compared with other proxy signals (e.g. diatominferred values).

\subsection{Macrofossil analysis}

Macroscopic remains of animals and plants (not shown; see Ssemmanda et al., 2005) are here referred to as macrofossils. At Kasenda, samples were analysed every $2 \mathrm{~cm}$ in the upper $20 \mathrm{~cm}$, and every 4-6 cm thereafter (total 45 samples), and at Wandakara, every $2 \mathrm{~cm}$ in the upper $40 \mathrm{~cm}$, then every $4 \mathrm{~cm}$ (total 63 samples). The volume of macrofossil samples was determined by 
displacement in water. The samples from the Russian cores (c. 20 to $100 \mathrm{ml}$ ) are much larger than those from the Kajak cores (c. $5 \mathrm{ml}$ for Wandakara and c. $25 \mathrm{ml}$ for Kasenda), which cover the upper part of the sequences. The errors associated with these smaller Kajak samples are correspondingly larger. Samples were wet sieved through 400, 200 and $100 \mu \mathrm{m}$ sieves, and the residue left on the sieves analysed in Petri dishes, using a dissecting microscope (x10-x50 magnification). Macrofossils were identified as far as possible using reference material and counted. Orthotrichia was identified according to Bennike and Wiberg-Larsen, (2002). The results are presented as accumulation rates (no. per $\mathrm{cm}^{2}$ per yr).

\subsection{Isotopic analyses of bulk organic matter and carbonates}

Carbon isotope ratios and $\mathrm{C}$ and $\mathrm{N}$ concentrations of organic matter $\left(\delta^{13} \mathrm{C}_{\text {org }}\right.$, \% TOC, \% TN from which we derived $\mathrm{C} / \mathrm{N}$ ) were analysed on samples from both lake sequences. Sampling strategy was the same for both lakes, namely every $2 \mathrm{~cm}$ in the upper $10 \mathrm{~cm}$, and every $\sim 4 \mathrm{~cm}$ thereafter (in total 47 samples for Kasenda, and 54 for Wandakara). The sediments were first treated with $10 \% \mathrm{HCl}$ at room temperature overnight to remove carbonates, rinsed and homogenised in agate. ${ }^{13} \mathrm{C} /{ }^{12} \mathrm{C}$ analyses were performed by combustion using a Carlo Erba 1500 on-line to a VG Triple Trap and Optima dual-inlet mass spectrometer. $\delta^{13} \mathrm{C}_{\text {org }}$ values were calculated to the V-PDB scale using a within-run laboratory standard (calibrated against NBS-19 and NBS-22; Lamb et al., 2004). Replicate analyses indicated a precision of $\pm 0.1 \%$ ( 1 s.d.). \% TOC and \% TN were measured simultaneously, and were calibrated against an acetanilide standard, for which replicate analyses indicated a precision of $<0.1 \%$. Atomic $\mathrm{C} / \mathrm{N}$ ratios are used throughout here.

Oxygen isotope analysis was only completed on the bulk sediments of Lake Kasenda (integrating any seasonal changes; Lamb et al., 2002), as it has a simple carbonate mineralogy (low-magnesium calcite, $~ 0.26 \%$ Mg; J.M. Russell, unpubl. data; Bessems, 2007). Lake Wandakara exhibited a more complicated mineralogy with high $\mathrm{Mg} / \mathrm{Ca}$ ratios and the presence of monohydrocalcite. Indeed $\delta^{18} \mathrm{O}$ and $\delta^{13} \mathrm{C}$ analyses of cores collected in 2001-2 (Bessems, 2007) show highly fluctuating values and poor reproducibility of results from this lake, most likely due to the highly heterogenous carbonate fraction and complex mineralogy of Wandakara sediments. 
For stable isotope analysis of authigenic carbonates $\left(\delta^{18} \mathrm{O}_{\text {carb }}, \delta^{13} \mathrm{C}_{\text {carb }}\right), 1-2 \mathrm{~cm}$ thick sediment samples from Lake Kasenda were taken every $2 \mathrm{~cm}$ in the upper $10 \mathrm{~cm}$, thereafter every 4-6 cm (total 44 samples). Sediments were gently disaggregated in 5\% sodium hypochlorite solution for 24 hours to oxidize reactive organic material. Samples were then washed three times in distilled water and sieved at $65 \mu \mathrm{m}$ to remove shelly fragments. The $<65 \mu \mathrm{m}$ fraction was dried at $40^{\circ} \mathrm{C}$ and ground in agate. The isolated material was reacted with anhydrous phosphoric acid in vacuo overnight at a constant $25^{\circ} \mathrm{C}$. The liberated $\mathrm{CO}_{2}$ was separated from water vapour and collected for analysis. Measurements were made on a VG Optima mass spectrometer. Overall analytical reproducibility for these samples was better than $0.1 \%$ for $\delta^{18} \mathrm{O}$ and $\delta^{13} \mathrm{C}(1 \mathrm{s.d}$.). Isotope values are reported as per mille (\%o) deviations of the isotopic ratios $\left({ }^{13} \mathrm{C} /{ }^{12} \mathrm{C},{ }^{18} \mathrm{O} /{ }^{16} \mathrm{O}\right.$ ) calculated to the VDPB scale using a within run laboratory standard calibrated against NBS standards.

\subsection{Numerical methods}

For diatoms, stratigraphic plots were divided into zones using CONISS (Grimm, 1987) with square root transformation of percentage data. Multivariate ordination techniques were used to highlight the main underlying patterns of variation among the major biological proxies (diatoms, chironomids, macrofossils), as an aid to comparing down core trends. Detrended correspondence analysis (DCA) on percentage abundance data (diatoms, chironomids) or square-root of flux (macrofossils) was used to determine the appropriate model (linear or unimodal) for further analysis, and principal component analysis (PCA) used if the gradient along the first DCA axis was less than c.1.5 units (ter Braak, 1995). Ordinations were implemented using CANOCO 4.54 (ter Braak and Šmilauer, 2002).

Surface water conductivity was inferred using a diatom transfer function largely developed from an extensive training set of contemporary western Uganda crater lakes (Mills, 2009). This model is both limnologically and floristically more appropriate than the pan-African

EDDI database, and has up to $50 \%$ lower error when internally validated $\left(n=69\right.$ samples, $r^{2}$ jack $=$ 0.74, RMSEP = 0.256 log units; K. Mills \& D. Ryves, unpublished data). Goodness-of-fit is assessed by considering the proportion of fossil data covered by the conductivity model (species 
coverage) in each sample and the sample dissolution index (F index). All quantitative reconstructions using diatom data were carried out using the $\mathrm{C} 2$ (v.1.6.6) software package (Juggins, 2003).

\section{Results}

\subsection{Diatom analysis}

The diatom stratigraphies of Lakes Wandakara and Kasenda are shown in Figures 2 and 3. All diatom species $>3 \%$ in any sample are shown as percentage abundance. Six assemblage zones were identified for Wandakara and 5 for Kasenda.

\subsubsection{Lake Wandakara}

Zone Wd1 (AD 1280 - 1390) consists of three rather different samples floristically, and suggests a transition between Nitzschia aff. bacillum in the bottom sample to an assemblage dominated by benthic-littoral forms. Diatom concentration in one sample (AD 1340) is extremely low (count $<100$ valves), but preservation is good $(\mathbf{F}=0.9)$, suggesting dilution of microfossils by nondiatomaceous sediment in this period. The significant proportion of subaerial (e.g. Hantzschia amphioxys (Ehren.) Grunow, Sellaphora seminulum (Grun.) D.G. Mann) and benthic (littoral) taxa (e.g. Amphora veneta Kütz., Navicula cincta (Ehren.) Ralfs) imply a catchment in-wash event, during a period of relatively low lake level. The uppermost sample in this zone is dominated by periphytic taxa (e.g. Encyonema spp., Gomphonema pumilum (Grun.) Reich. \& Lange-Bert. and the epiphytic Cocconeis placentula var. euglypta (Ehren.) Grun.), suggesting these habitats were nearer the core site, and thus generally low lake level but not saline conditions.

In zone $\mathrm{Wd} 2(\mathrm{AD} 1390$ - 1425) there is an abrupt switch to an assemblage dominated by Cyclotella meneghiniana Kütz. (between 60-80\%), a diatom often linked to more saline conditions in both Africa and America (Fritz et al., 1993; Gasse et al., 1995) in marked contrast 
to its distribution in the Ugandan crater lakes training set (Mills, 2009). Diatom concentrations and preservation within this zone are both high. Almost as abruptly, this species disappears from the assemblage, which marks the start of zone $\mathrm{Wd} 3$ (AD 1425-1850). This zone is characterised by a relatively stable association of periphytic Cocconeis, Encyonema, Gomphonema and Amphora taxa, again implying lower lake level (as at the top of Wd1). Concentrations fluctuate, but tend to increase from the middle of the zone, in parallel with improving diatom preservation.

Zone Wd4 (AD 1850 - 1905) defines the second major appearance of C. meneghiniana, which reaches $90 \%$ by AD 1895, again with high concentrations of valves and good preservation, similar to zone Wd2. Zone Wd5 (AD 1905 - 1990) is similar to zone Wd3, although the freshwater epiphytic diatom Synedra acus Kütz. and the more saline-indicating Nitzschia aff. bacillum are both more significant in the assemblage. Floristic diversity (as $\mathrm{N}_{2} ;$ Hill, 1973) reaches maximum values for the sequence during this zone. The uppermost 4 samples (zone Wd6; AD 1990 - 2000) are dominated by the Nitzschia aff. bacillum with a minor component of C. meneghiniana and $S$. acus, suggesting fluctuating conditions of salinity.

Species coverage is good (average 83\%). DI-conductivity is highest in zone $\mathrm{Wd} 1$, at the base of the sequence, and in the recent sediments of Wd6, with the model slightly overestimating values in the surface sediment $\left(\sim 2200 \mu \mathrm{S} \mathrm{cm}^{-1}\right)$ compared with field measurements in 2000 of $\sim 1270 \mu \mathrm{S} \mathrm{cm}^{-1}$. Low values are inferred during much of zone $\mathrm{Wd} 3$, contrary to expectation from a diatom flora dominated by littoral-benthic taxa, while the two periods dominated by $C$. meneghiniana ( $\mathrm{Wd} 2$ and $\mathrm{Wd} 4)$ do not stand out as high salinity episodes. Salinity drops fairly sharply across the boundary from $\mathrm{Wd} 3$ to $\mathrm{Wd} 4$, halving from $\sim 1900$ to $\sim 800 \mu \mathrm{S} \mathrm{cm}^{-1}$ around AD 1850.

\subsubsection{Lake Kasenda}

In the lowermost zone Kd1a-1c (AD 740 - 1000), littoral-benthic taxa (e.g. Navicula cryptotenella Lange-Bert. and Amphora copulata (Kütz.) Schoeman \& Archibald) and epiphytic forms (e.g. Cymbella, Encyonema and Gomphonema spp.) account for up to $80 \%$ of the assemblage, with a single level in which the epiphytic freshwater Synedra acus is important in zone Kd1a. Diatom concentrations and preservation index are low, and there is a small $(<1 \%)$ but 
consistent presence of subaerial taxa throughout the zone (e.g. H. amphioxys). Taken together, this suggests that the lake was far lower at this time.

Zone Kd2 (AD 1000 - 1060) consists of two samples with high relative (>60-90\%) and absolute abundance of the freshwater diatom Aulacoseira granulata var. angustissima (O. Müll.) Simonsen. Unlike the nominate variety, which is associated with deeper water (Stager et al., 1997; Talling, 1966), this variety has been linked to shallow, benthic freshwater habitats (Gasse, 1986; Lamb et al., 2007a). The only other important taxon in this zone is the more saline Nitzschia aff. bacillum which increases in importance into zone $\mathrm{Kd} 3$.

Zone Kd3 (AD 1060 - 1220) is the first period that the higher salinity Nitzschia aff. bacillum dominates the record. As benthic and littoral taxa decline in importance, diatom concentration and preservation increase, concomitant with the disappearance of the freshwater $A$. granulata var. angustissima. Kilham et al., (1986) consider that the Nitzschia fonticola Hust. group (sensu latu, which we argue would include the $N$. bacillum group) is obligate nitrogen heterotrophic and found in association with the cyanophyte Microcystis aeruginosa (Kütz.) Kütz. which culturing experiments has shown is affected little by salinity up to $10 \mathrm{~g} \mathrm{~L}^{-1}$ (Tonk et al., 2007). We therefore interpret abundance of this taxon as indicative of elevated salinity, perhaps under stably stratified (though not necessarily deep water) conditions (Stager et al., 1997).

Zone Kd4 (AD 1220 - 1960) covers a long period when the Nitzschia aff. bacillum dominates, with occasional episodes where epiphytic taxa (notably Cocconeis placentula var. euglypta, Gomphonema, Encyonema and Cymbella) are important. During these periods, diatom concentration and preservation both decline, suggesting that this represents a suppression of the Nitzschia aff. bacillum, rather than a large increase in the productivity of the littoral-benthic taxa. Lake level is likely to have remained fairly low throughout the period of Nitzschia aff. bacillum dominance. However, during zone $\mathrm{Kd} 4 \mathrm{~b}$ around AD 1700, when there is a sharp increase in freshwater periphytic taxa (and the re-appearance of the freshwater A. granulata var. angustissima), lake waters became more dilute, with likely some concomitant lake level rise.

Zone Kd5 (AD 1960 - 2000) exhibits much higher floral diversity than Kd4, notably the appearance of the freshwater littoral form Planothidium rostratum (Østrup) Round \& Bukhtiyarova, and taxa indicating elevated conductivity, such as Nitzschia inconspicua Grun.. 
There is a trend within the last 40 years of the record of lowering conductivity, with the Nitzschia aff. bacillum present throughout. The decline in periphytic and especially epiphytic taxa (e.g. Cocconeis placentula) may be related to known catchment and lakeshore disturbance (leading to increasing turbidity and littoral sedimentation).

Fossil data are very well covered by the conductivity model, with on average $92 \%$ of species abundance data included. Low DI-conductivity zones Kd1a do not agree with diatom assemblage indicators of low lake level here, but increasing DI-conductivity in zones Kd1b and Kd1c do. Values fall again in $\mathrm{Kd} 2$, but rise steadily thereafter through $\mathrm{Kd} 3$ and $\mathrm{Kd} 4$, when Kasenda was slightly saline with conductivity around $3000 \mu \mathrm{S} \mathrm{cm}^{-1}$. Conductivity falls around AD 1400, and especially at $\sim$ AD 1700, returning to higher values by $\sim$ AD 1800 before freshening until the present day. Current measurements $\left(\sim 380 \mu \mathrm{S} \mathrm{cm}^{-1}\right.$ in 2000$)$ agree reasonably well with the $0-1 \mathrm{~cm}$ sample $\left(550 \mu \mathrm{S} \mathrm{cm}^{-1}\right)$.

\subsection{Chironomid analysis}

A total of 1898 chironomid head capsules and Chaoborus (phantom midge) mandibles were examined from Lake Wandakara (Fig. 4). The total concentration of chironomid remains was extremely low with only $2-4$ head capsules per gram wet sediment. The average total count per sample was 90 head capsules. A total of 21 chironomid taxa were identified. There were no significant correlations between sample counts and taxonomic richness $(p=0.22$ number of taxa; $\left.p=0.81 \mathrm{~N}_{2}\right)$.

Chironomid taxa are arranged horizontally according to their WA salinity optima (Eggermont et al., 2006, Appendix A). The chironomids Ablabesmyia and Dicrotendipes spp., along with Chaoborus, have similar distribution patterns. Tanytarsus type horni Goetghebeur, Polypedilum and Cricotopus also show similar stratigraphical patterns. Xenopelopia/Paramerina and Procladius are characteristic for the uppermost core sections. Nilodorum type fractilobus Kieffer was the overall dominating taxon, making up 39\% of the chironomid head capsules followed by Dicrotendipes type fusconotatus Kieffer as subdominant (15\%). 
Results of detrended correspondence analysis (DCA; Fig. 4) showed that a systematic direction in development of Lake Wandakara could not be found, with DCA axis 1 driven by the profile of Nilodorum fractilobus. The major differences in the chironomid profile are controlled by the dominance of Nilodorum fractilobus and Dicrotendipes fusconotatus which have a distribution restricted to the more dilute $\left(<1200 \mu \mathrm{S} \mathrm{cm}^{-1}\right)$ African lakes (Verschuren 1997). As these two species together make up 38-80\% of the head capsules throughout the core, it is difficult to make convincing interpretations on changing salinity from the chironomid profile. Except for an isolated occurrence of Kiefferulus type disparilis Goetghebuer (WA-optimum of $10,754 \mu \mathrm{S} \mathrm{cm}^{-1}$ ), all other taxa have moderate salinity optima, ranging from $288-652 \mu \mathrm{S} \mathrm{cm}^{-1}$ (Eggermont et al., 2006). However, one of the clear excursions in the DCA axis 1 and 2 scores ( $\sim \mathrm{AD} 1450)$ was characterised by low chironomid diversity and presence of the salinity tolerant Kiefferulus type disparilis.

\subsection{Macrofossil analysis}

Even though the two lakes are of similar size and depth, the concentration of macrofossils is considerably higher in the sequence from Wandakara than that from Kasenda, despite higher sedimentation rates. In concert with the diatom flora, there are also many more remains of littoral taxa in Wandakara than in Kasenda, suggesting that the littoral zone is better represented in Wandakara.

\subsubsection{Lake Wandakara}

The Wandakara sequence (Figure 5a) contains freshwater animals, represented by shells of ostracods, larval cases of caddis flies (Orthotrichia sp.), shells of snails and bones and scales of fish. The latter are present throughout the sequence, which means that fish have been present in the lake during the last 700 years, long before humans began to introduce fish to lakes in Uganda. Fish, fresh water invertebrates and water plants were probably introduced to the lake by water birds, such as ducks, divers and herons, which travel from one lake to the next. Shells of at least 
five species of ostracods are present. Some of the species are present in very low numbers, but one taxon, Cypridopsis sp., is common.

\subsubsection{Lake Kasenda}

Both the diversity and concentration of macrofossils are lower in the Kasenda sequence (Figure $5 b)$ than in the Wandakara sequence. No snail shells were found in the sequence, but opercula of the prosobranch snail, Bithynia sp., are present in the upper part of the sequence. The opercula consist of calcite, whereas the shells of this genus and other gastropods consist of aragonite. Although aragonite is generally more unstable than calcite, it is unlikely to have been preferentially removed after the death of the snail by diagenetic dissolution processes, as the time span involved is short and calcite preservation in the core is good. We can perhaps speculate that the shells of Bithynia floated to the water surface and were transported by wind to the shore. The fish record in Kasenda extends 1200 years back in time, with the large numbers of fish bones and scales in the lowest sample suggesting a major fish kill, perhaps due to a drying event at low water level.

4.4 Bulk organic $\left(C / N\right.$ and $\left.\delta^{13} C_{\text {org }}\right)$ and carbonate $\left(\delta^{18} O_{\text {carb }}\right.$ and $\left.\delta^{13} C_{\text {carb }}\right)$ isotopes

\subsubsection{Lake Wandakara (Fig. 6a)}

The $\mathrm{C} / \mathrm{N}$ from the sediments range from $\sim 9.9$ to 17.9 , indicating a mixture in the source of the material (perhaps algae/macrophytes and terrestrial material) for most of the record. At $\sim \mathrm{AD}$ 1400 , the $\mathrm{C} / \mathrm{N}_{\text {atomic }}$ drops to its lowest value of 9.9 , possibly suggesting a period of algal domination (Meyers and Teranes, 2001); this minimum in the $\mathrm{C} / \mathrm{N}_{\text {atomic }}$ coincides with a peak in diatom concentration (Fig. 2). Starting around AD 1950, C/N $\mathrm{N}_{\text {atomic }}$ declines towards the top of the core, with a surface sediment ratio of 12.6.

The $\delta^{13} \mathrm{C}_{\text {org }}$ values fluctuate between -20 and $-23 \%$ o through most of the core although higher (more positive) values (up to -10\%) occur, before AD 1350, and at AD 1450 and 1700. 
Talbot and Livingstone, (1993) found that the $\delta^{13} \mathrm{C}_{\text {org }}$ values of lake sediments in $\mathrm{C}_{4}$-dominated landscapes in eastern Africa varied from $-10 \%$ to $-15 \%$, and the more positive values (along with $\mathrm{C} / \mathrm{N}>10$ ) could indicate an in-flux of $\mathrm{C}_{4}$ plants, indicating drier conditions. The higher

$\delta^{13} \mathrm{C}_{\text {org }}$ values at the base of the sequence, coincident with a rise in charcoal macrofossils, may indicate vegetation change associated with catchment fires (Wooller et al., 2000). The $\delta^{13} \mathrm{C}_{\mathrm{org}}$ record rises from $\sim$ AD 1375 - 1450, and peak values coincide with maximum chironomidinferred salinity. $\delta^{13} \mathrm{C}_{\text {org }}$ values remain low until a rise during the "low organic event" at $\sim \mathrm{AD}$ 1700, which concurs with its interpretation as a catchment in-flux event at the end of an arid period.

\subsubsection{Lake Kasenda (Fig. 6b)}

$\mathrm{C} / \mathrm{N}_{\text {atomic }}$ ratios from this core range from $\sim 12.8$ to 18.6 , which represents a mixture of both aquatic and higher plant material, typical of lacustrine sediments (Lamb et al., 2004). Values are highest at the bottom of the core ( AD 750 - 1350) where they fluctuate between 16 and 18 . At approximately $\mathrm{AD} 1400$ a drop in $\mathrm{C} / \mathrm{N}_{\text {atomic }}$ to $\sim 15$ occurs, and the record then plateaus at $\sim 15$ before declining towards the top of the core to a surface sediment ratio of 12.8 .

Values of $\delta^{13} \mathrm{C}_{\text {org }}$ range from -28 and $-17 \%$, indicating a mixed source of $\mathrm{C}_{3}$ and $\mathrm{C}_{4}$ plants (Talbot and Livingstone 1993). The low $\delta^{13} \mathrm{C}$ values $(-26$ to $-25 \%$ ) and high $\mathrm{C} / \mathrm{N}$ at the base of the Kasenda sequence may indicate a contribution from $\mathrm{C}_{3}$ type plants (cf. Boutton et al., 1999). Between $\mathrm{AD} 950$ and 1250 , the $\delta^{13} \mathrm{C}_{\text {org }}$ record reaches its highest value (peaking at $-17 \%$ ), suggesting either more $\mathrm{C}_{4}$ terrestrial plants in the catchment or a greater contribution from aquatic plants with high $\delta^{13} \mathrm{C}_{\mathrm{org}}$, although there is no suggestion of aquatic dominance in the $\mathrm{C} / \mathrm{N}$. Values then rapidly decline to around $-26 \%$. After this, $\delta^{13} \mathrm{C}_{\mathrm{org}}$ slowly rises to $-22 \%$ at $\sim \mathrm{AD} 1450$, with a slight fall to $-26 \%$ at $\sim \mathrm{AD} 1500$, rising again to $-22 \%$ ountil $\sim \mathrm{AD} 1700$. The last 300 years of the record is characterised by steadily decreasing values, reaching $-28 \%$ in the uppermost sediments.

Values of $\delta^{18} \mathrm{O}_{\text {carb }}$ range from -3.0 to $+2.0 \%$, with the record characterised by two troughs at $\sim \mathrm{AD} 1000$ and $\sim 1700$, with values of $-3.0 \%$ and $-1.5 \%$ respectively. The earliest 
sample has a higher value $(+1 \%$ ), after which values fall, before steadily rising to the highest value recorded in the sequence $(+2.0 \%)$. This is followed by a gradual decline towards $0 \%$, before dropping very sharply to low values just after AD 1000 (replicate analysis of this sample measured -2.9\%o). Subsequently, $\delta^{18} \mathrm{O}_{\text {carb }}$ increases sharply. The middle part of the record ( AD 1050 - 1500) appears to be more stable, with no large excursions and values rising from $+0.5 \%$ to $+1.5 \%$. After AD 1500, values decline, reaching a low of $-1.5 \%$ at $\mathrm{AD} 1700$. Thereafter $\delta^{18} \mathrm{O}_{\text {carb }}$ rises (+1.5\%o, AD 1750) before declining steadily towards $0 \%$ ( AD 1850), finally rising to $+1.4 \%$ ( $\sim \mathrm{AD} 1940)$. The record contained in the uppermost sediments has large fluctuations between $-0.7 \%$ and $+1.5 \%$ before reaching a present day value of around $+0.1 \%$.

The $\delta^{13} \mathrm{C}_{\text {carb }}$ record is similar to the $\delta^{18} \mathrm{O}_{\text {carb }}$ record between $\sim \mathrm{AD} 1000$ and 1730, but in the earliest and latest parts of the sequences (AD 800 - 1000 and AD 1730 to present, respectively) the profiles appear to have an inverse relationship. In the earlier parts of the record, $\delta^{13} \mathrm{C}_{\text {carb }}$ values fluctuate around +4 to $+5 \%$, rising to one of the highest values seen in this record (+7.3\%o) before falling sharply to $-0.2 \%$ at $\sim 1000 \mathrm{AD}$ (one of the lowest values in the record). Following these extremes, the middle part of the record stabilises (as with the $\delta^{18} \mathrm{O}_{\text {carb }}$ record), fluctuating between +4 to $+6 \%$. Low values in the $\delta^{18} \mathrm{O}_{\text {carb }}$ at $\sim \mathrm{AD} 1300$ are not replicated in the $\delta^{13} \mathrm{C}_{\text {carb }}$ record. Between AD 1600 and $\sim 1730$ the record once again appears to co-vary with the $\delta^{18} \mathrm{O}_{\text {carb }}$. There is a peak at AD 1650 to the highest value seen in this record $(+7.8 \%$ ) coincident with the later trough in the $\delta^{18} \mathrm{O}_{\text {carb }}$. The $\delta^{13} \mathrm{C}_{\text {carb }}$ record of the last 270 years is very different to that recorded in the $\delta^{18} \mathrm{O}_{\text {carb }}$. The values steadily decline to their lowest value of $-0.6 \%$ (AD 1850). From this point upwards the values remain low, fluctuating around $0 \%$ (range between -0.2 and $+1.2 \%$ ). The records from the $\delta^{13} \mathrm{C}_{\text {carb }}$ and $\delta^{13} \mathrm{C}_{\text {org }}$ also show similarities, though the early trough in the $\delta^{13} \mathrm{C}_{\text {carb }}(\sim \mathrm{AD} 1000)$ is not found in the $\delta^{13} \mathrm{C}_{\text {org }}$ record.

\section{Discussion}

\subsection{Coherence and contrast between Lakes Wandakara and Kasenda}

Within the constraints of our chronologies, there is some degree of coherence within each lake's sedimentary record indicating common trajectories of lake development, though the 
expression of these differs between lakes for the same proxy, despite these crater lakes sharing similarities in size and depth. Given the proximity of these small, relatively shallow closed crater lakes, they can be expected to share common geological and climatic histories, and it is clear from pollen records (Ssemmanda et al., 2005) that catchment and regional vegetation changes have been remarkably similar over the past 700 years. However, for much of this time, Kasenda has been the more saline lake, precipitating substantial calcite from algal photosynthesis (Fig. 6b; Bessems, 2007) in a system dominated by cyanobacteria (associated with $N$. aff. bacillum). Kasenda has freshened appreciably during the last 100 years, while Wandakara has become more saline in the last 50 years. For much of the last 1200 years, evidence suggests that these lakes would not have been equally attractive to human populations as freshwater resources.

In general terms, the sedimentary records demonstrate that there are important differences in lake functioning between Kasenda and Wandakara, as might be expected from their bathymetries and catchment:lake areas (Bessems, 2007; Russell et al., 2009). While Kasenda has steep sides with a relatively large, flat profundal zone, Wandakara slopes more gradually to its maximum depth. The role of the littoral zone is greater in Wandakara, where the shore is only about $100 \mathrm{~m}$ from the deepest point, compared with $\sim 300 \mathrm{~m}$ at Kasenda. This is clearly reflected in the greater numbers or proportions of littoral and benthic remains found in Wandakara (diatoms, macrofossils and chironomids) compared with Kasenda (where almost no fossil chironomids were recorded). Catchment processes affecting run-off generation and associated limnological processes are also likely to be more important at Kasenda, with a catchment:lake area of $\sim 16$ compared with $\sim 3$ at Wandakara (lake and catchment areas calculated using a digital elevation model; K. Mills, unpubl. data). The two lakes can therefore also be expected to differ in their response to climatic change as Kasenda's lake water balance should be more sensitive to changes in effective moisture (P-E) over the larger catchment.

Human activity within the catchments may well have altered each lake's sensitivity to climate. Over the entire records, diatom assemblages (as summarised by DCA axis 1 scores) show low correlation with DI-conductivity ( $r=0.279$ for Kasenda, and 0.317 for Wandakara; $p$ > 0.05 for both with a 2-tailed test). Considering only the pre-1900 (pre-colonial) period, however, Kasenda DCA axis 1 scores are highly correlated with conductivity $(r=0.843, p<0.001)$, while Wandakara remains non-significant $(r=0.117)$. Correlation with the diatom DCA second axis at 
Wandakara is significant pre-1900 $(r=0.464, \mathrm{p}<0.03)$, suggesting that climate is a secondary driver of diatom communities at this lake over the last 700 years at least. This agrees with Russell et al. (2009) who provide organic molecular evidence that human activity altered catchment and lake biogeochemistry at Wandakara, especially of N, since AD 1250. Russell et al. (2009) also speculate that $\mathrm{N}$ availability in the lake was low until $\sim \mathrm{AD} 1250$, favouring development of bluegreen $\mathrm{N}$-fixing cyanobacterial, from which point human activity in the catchment (deforestation, agriculture and field manuring) lead to increasing $\mathrm{N}$ inputs to the lake. Our diatom record supports this sequence of events, with high abundance of Nitzschia aff. bacillum (considered an obligate N-heterotroph associated with cyanobacteria; Kilham et al., 1986) until AD 1300, and thereafter its dramatic decline until the latter 1700s.

Other evidence also points to the important role of nutrients at Wandakara, rather than salinity per se, over the last 700 years. In semi-arid areas, Cyclotella meneghiniana has usually been linked to elevated salinity from various datasets (e.g. Fritz et al., 1993; Gasse et al., 1995), but its salinity optimum in the Uganda crater lake model used here is relatively low. Its major occurrence in Wandakara centred on AD 1400 and AD 1870 is not associated with any other indicators of high salinity in any of the proxies. Cyclotella meneghiniana is found in the plankton in nutrient-enriched lakes in diverse landscapes (e.g. Bradshaw et al., 2002; Dong et al., 2008), and so may be more indicative of higher productivity rather than increased salinity. Inputs of nutrients from the catchment, and/or increased availability within the water column (from cyanophyte decomposition or recycling from profundal sediments), together with lower salinity (a wetter period) may have provided ideal conditions for a short period when this diatom could bloom. Diatom evidence from Kasenda shows evidence of lower salinity at both these times (the latter coinciding with wet conditions across eastern Africa in the 1870s). Diatom concentrations are high at both times (Fig. 2), and $\mathrm{C} / \mathrm{N}$ ratios suggest that, at least for the earlier event, algal productivity dominates organic sedimentation (Fig. 6a). As sedimentation may be greater under conditions of higher productivity, these episodes may be shorter than the age-depth model (based on longer-term sedimentation rates) suggests. Here we interpret these peaks of $C$. meneghiniana at Wandakara as predominantly nutrient-catalysed blooms under lower salinity.

Inferred conductivity at Wandakara may be low from AD 1450 - 1700, when Kasenda registers high salinity, due to hydrological controls (e.g. groundwater removal of salts, 
anthropogenic alteration of catchment vegetation producing greater runoff under cultivation), or due to a modelling artefact, whereby diatom assemblages, driven by nutrient concentration, infer unreliable conductivity. Assemblages dominated by benthic and periphytic taxa (Amphora, Cocconeis, Gomphonema and Cymbella), however, do indicate shallow water throughout this period, supporting evidence of a regionally drier phase at this time. The low-oxygen tolerant Chaoborus has low abundance at these times (and AD 1750 - 1850, during another dry phase; Fig. 4), supporting evidence of lower lake level, and sufficient mixing to prevent stratification and anoxia (cf. Cohen et al., 2007). Quasi-permanent meromixis (and accompanying profundal anoxia) is widespread in sheltered crater lakes across western Uganda of even modest water depth (Melack, 1978; Mills, 2009).

Two short-lived, wet periods are also implied by two low DI-conductivity episodes at Kasenda around AD 1000 and 1700 driven by high abundance of the centric diatom Aulacoseira granulata var. angustissima. Although generally considered planktonic (e.g. Gasse 1986), the A. granulata group can thrive in lower light levels (e.g. in eutrophic lakes; Kilham et al., 1986), and this variety has been linked to turbid, shallow water conditions (Lamb et al., 2007a), and thus need not imply a deep lake. In the Kasenda record, it is associated with other freshwater or weakly saline benthic and littoral/epiphytic diatoms (e.g. Amphora copulata bracketing the peak at AD 1000, and Cocconeis, Gomphonema, Encyonema and Cymbella spp. important in the assemblage $\sim \mathrm{AD} 1700$ ), suggesting proximity to littoral habitats, or inwash from these areas, during such times of lower salinity. At both times, a negative excursion in the $\delta^{18} \mathrm{O}_{\text {carb }}$ profiles suggests reduced evaporative concentration of lake water. Although it is not straightforward to compare carbonate with water $\delta^{18} \mathrm{O}$ values, $\delta^{18} \mathrm{O}$ values are more similar to groundwater (c. $-2 \%$; K. Mills \& J.M. Russell, unpubl. data), in contrast to current lake water values indicating net evaporation (values between +2 to $+4 \%$; K. Mills \& J.M. Russell, unpubl. data). Lithological evidence points to a reduction of calcite precipitation under lower salinity at both times (Fig. 6b), as while large parts of the record over the last 1200 years are laminated (Bessems, 2007), neither of these sections is. Similarly, magnetic susceptibility values (Fig. 6b) increase around both events, suggestive of enhanced in-wash from the catchment and/or enhanced transport from greater runoff. Chironomid WA-conductivity values at Wandakara also suggest a freshening event $\sim$ AD 1700 (Fig. 4), with increased Chaoborus abundance as stratification and anoxia become briefly re-established. 
The individualistic behaviour of these lakes highlights the value (and indeed necessity) of a multiproxy (and multidisciplinary) approach to understand, identify and separate local events and conditions from broader, regional signals from sedimentary records which filter these through processes idiosyncratic to each lake-catchment system. Similarly, Street-Perrott et al., (2007) found that long-term lake ontogeny differed widely between lakes at different elevations on Mt. Kenya, and ascribed this to limnological variation, though clearly influenced by climate. By comparing independent lake level reconstructions inferred from proxy records at each lake, common patterns in change, implying regional-scale processes, can be more easily discerned. These are presented and discussed in relation to other regional records below.

\subsection{Comparison with regional palaeolimnological records}

Figure 7 presents selected regional proxy lake level records based on a variety of geochemical, sedimentological and biotic indices, together with diatom-inferred conductivity from Wandakara and Kasenda. While dating remains problematic for some periods for many records (not least as

this spans the interval between ${ }^{210} \mathrm{~Pb}$ dating methods and ${ }^{14} \mathrm{C}$ dating), some patterns in the spatial and temporal signature of climate change across equatorial eastern Africa in the last millennium are beginning to emerge.

The early record of low lake level from Kasenda (dominated by benthic diatoms, evidence of fish kills, but low salinity) around AD 750 finds some echo in the record from Lake Edward (where aridity begins earlier; Russell and Johnson, 2005), and to some extent from Kitagata (Russell et al., 2007; Fig 7c). Nile levels are thought to have been low from AD $720-800$ and high from AD 800 - 920 (Nicholson, 1998). Although the Kasenda record cannot be compared with Wandakara in this period, other evidence for vegetation and catchment disturbance near Kasenda (at Kabata Swamp, $5 \mathrm{~km}$ to the north; Taylor et al., 1999) around AD 800 might have a climatic explanation.

There is substantial evidence for a widespread arid phase around AD $1000-1200$, which is seen across the region from Ethiopia, Kenya and Tanzania, to western Uganda, from Lakes Hayq (Lamb et al., 2007b), Naivasha (Verschuren et al., 2000), Emakat (Ryner et al., 2008), Victoria 
(Stager et al., 2005), and Edward (Russell and Johnson, 2005), but also in smaller basins such as saline Lake Kitagata, close to Edward (though not at nearby freshwater Lake Kibengo, hydrologically a sub-basin of the much larger Lake George, Russell et al., 2007; Fig. 7d). The pollen data from Kasenda (Ssemmanda et al., 2005) also point to a decline in regional forests from around AD 900 - 1000, which can be largely interpreted as a period of increasing aridity (although also coinciding with the onset of the later Iron Age in western Uganda; Taylor et al., 2000). The Kasenda sedimentary record (including lithological evidence of alternating laminated/non-laminated sections; Bessems, 2007, and the A. granulata peaks; Fig. 3) points to generally low lake levels until $\sim$ AD 1000, wetter over AD 1000 - 1100, and increasingly dry conditions from then until AD 1350. Within dating errors, the palaeoconductivity record from Kasenda agrees well with records from Kitagata and Victoria (Fig. 7f, where increasing \% of shallow water diatoms (SWD) indicate lower lake level; Stager et al., 2005). This increasing aridity agrees with the record from Lake Edward until $\sim$ AD 1200, after which the records diverge, Edward recording wetter conditions from AD 1200-1400 (though there are oscillations in this period). The establishment of major, permanently inhabited settlements such as Ntusi in the grasslands west of Lake Victoria (Robertshaw et al., 2004) may be linked to generally wetter conditions until around AD 1100.

As the catchment area of Edward extends to the Virunga volcanoes at $2^{\circ} \mathrm{S}$, this might point to a gradient of moisture availability within western Uganda from AD 1200 - 1400, with a drier north (and east; cf. Victoria; Fig. 7f) and a wetter south, although lake-specific factors may partly explain this (e.g. Kibengo, which does not show clear evidence for drier conditions until $\sim$ AD 1400; Fig. 7d). However, as other major arid phases across western Uganda are seen in records in both northern and southern lake districts, and as there is often a climatic imprint within the Wandakara record that supports that from Kasenda, we suggest that climatic variability had a more complex, and finer-scale, spatial pattern at times over the late Holocene.

Conditions became briefly wetter at Kasenda around AD 1400, as also seen at Wandakara (cf. peak in Chaoborus abundance $\sim \mathrm{AD} 1350$ as discussed above in relation to deeper, stratified water and anoxia; Fig. 4) at the start of the record and noticeably a short-lived low SWD\% event at Victoria (Fig. 7f). After AD 1400, high conductivity values are again inferred at Kasenda, but remains low at Wandakara. Pollen spectra at Kasenda from AD 1000 (and Wandakara from AD 
1300) are dominated by grasses until the 1700s, with generally higher proportions of aquatic taxa from AD 1200 to 1600 (Ssemmanda et al., 2005). Human activity may explain the mismatch between pollen data and DI-conductivity at Wandakara (see Section 5.1), though diatom habitats do suggest low lake level. Additionally, indicators of catchment disturbance (magnetic susceptibility) and fire (charcoal flux) are elevated (Fig. 6a), as suggested by Russell et al. (2009).

The return to low lake level (and higher salinity) inferred at Lake Kasenda after AD 1400 appears a little earlier than at Lake Kibengo, though agreeing well with changes seen at Lake Edward, and is opposite to higher levels inferred at Lake Victoria (Fig. 7f). While the base of Wandakara is well dated (with paired AMS dates on terrestrial macrofossils; Ssemmanda et al., 2005), dating in this period is less certain at Kasenda (although supported by a correlated AMS ${ }^{14} \mathrm{C}$ date from Bessems, 2007; Fig. 7) and the southern lakes (Russell et al., 2007), and so these changes may in fact be synchronous across western Uganda. Lake Kasenda lake level is low until the late 1600s, as seen at Lakes Edward, Kibengo, and, to a lesser extent, Kitagata (Fig. 7), in marked contrast to Victoria, where high lake level is implied. As hypersaline Lake Kitagata also provides indications of aridity during the 1500s and 1600s and is unlikely to have been exploited as a water resource, it seems reasonable, as Russell et al. (2007) suggest, to interpret the pollen data from Kasenda and Wandakara from the 1400s - 1700s (discussed in Ssemmanda et al., 2005) largely in climatic terms, as a regional arid interval. In the light of these data, aridity from the 1400s in western Uganda may help explain the abandonment of Ntusi at this time (Robertshaw and Taylor, 2000), and a shift in settlement to sites further north (Robertshaw and Taylor, 2000; Taylor et al., 2000).

Within this generally dry period, a wet event is recorded at Kasenda AD 1700, while intense sediment deposition is dated to this period in Wandakara. Kibengo shows a drop in carbonate values, with little response at Kitagata, and \%SWD at Victoria likewise fall. However, aridity is inferred throughout this time at Edward (Fig. 7e, though the drop in $\mathrm{Mg} \%$ from AD $1700-1800$ may refer to the same event, as an artefact of dating errors in our records at this time). Dry conditions return again in the latter 1700 s and early part of the $19^{\text {th }}$ century, seen at both Kasenda and Wandakara, and at Edward and Victoria, before wetter conditions returned across eastern Africa from the 1850s. Local hydrological conditions clearly were important in controlling lake 
response (cf. Street-Perrott et al., 2007) as drought in the late $18^{\text {th }} /$ early $19^{\text {th }}$ centuries was severe enough to dry out Lake Kanyamukali, a $12 \mathrm{~m}$ deep freshwater crater lake only $5 \mathrm{~km}$ south-west of Wandakara in the Kasenda cluster, as well as Lake Chibwera $70 \mathrm{~km}$ to the south, near Kitagata and Kibengo on the rift floor (Bessems et al., 2008). Widespread drought in western Uganda during the latter 1700s may also be linked to the decline and abandonment of nucleated settlements to the east (such as the archaeological sites Kibengo [near Lake Albert], Munsa and Bigo; Fig. 1b), and the rise of pastoralism over agriculture (Robertshaw and Taylor, 2000).

Spatial complexity in climate across eastern Africa from AD $1400-1850$ is also highlighted from regional records. Drought across western Uganda from AD $1400-1600$ is not seen at Victoria, while records are largely concordant (given dating errors) after this time, and certainly from the late 1700s (widespread drought of the early 1800s giving way to wetter conditions by mid-century). Elsewhere, high lake levels are inferred at Lake Abiyata during the $18^{\text {th }}$ century $\left(7^{\circ} 37^{\prime}\right.$ N , 38 37' E, $1578 \mathrm{~m}$ a.s.1, Legesse et al., 2002), while a record from northern Tanzania (Lake Emakat, 2 55’ S, 35 50’ E, 2300 m a.s.l.; Ryner et al., 2008) suggests aridity lasing several decades in the interval $\sim \mathrm{AD} 1400$ to $\sim \mathrm{AD} 1700$. A multiproxy palaeoenvironmental

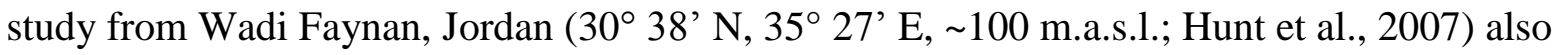
concluded that the LIA was a time of aridity in the eastern Mediterranean, which may imply the eastern end of the short-term climatic "see-saw" of the Mediterranean basin (driven by the North Atlantic Oscillation; Roberts et al., 2004) extended much further south at this time. Direct comparisons (and thus implied teleconnections) with the LIA of higher latitudes should be treated with some caution, however, as over this $\sim 300$ year period of colder conditions in northern Europe ( AD 1600 to 1900$)$, there is clear evidence from Kasenda of both wet and dry climate (Fig. 7).

\section{Conclusions}

Sediment records from smaller lakes clearly have much potential to contribute to our understanding of past environments, and can add high spatial and temporal resolution to such studies. Yet local factors can mask regional signals, and therefore strategies are required that identify individualistic response to local conditions rather than regional patterns. Multiproxy 
approaches can provide internal validation of a single lake record, while using paired (or multiple) lakes can separate local from regional responses. High quality palaeolimnological data can provide independent validation of climate model forecasts by challenging model hindcasts at high spatial and temporal resolution. Further work is needed to examine the different environmental gradients affecting proxies (e.g. diatom communities) in modern African landscapes and thus improve their value as (palaeo)environmental indicators.

While Kasenda appears to be climatically sensitive over much of the record, and Wandakara much more impacted by human activity (Russell et al., 2009), there is often coherence between the sedimentary records. In western Uganda, generally dry conditions are inferred from $\mathrm{AD} 700$ to 1000, with aridity increasing after AD 1100 until 1600, with a wetter period around AD 1000, and AD 1400 (the latter seen at both lakes). Wetter conditions around AD 1700 give way to a widespread arid phase in the latter $18^{\text {th }}$ and early $19^{\text {th }}$ century (which desiccated many other regional lakes; Bessems et al., 2008), followed by a return to wetter conditions in the mid-1800s. Equatorial eastern Africa seems to share the same climate history over much of the last millennium (aridity in the $12^{\text {th }}$ and $13^{\text {th }}$ centuries, and the early $1800 \mathrm{~s}$; wetter conditions around AD 1400 and the latter 1700s), but crucially the dry period recorded across western Uganda in the 1400s and 1500s is opposite to that observed to the east, and the south (Tierney et al., 2010). These complex spatial patterns appear to have no analogue in modern observations (Nicholson, 1986).

\section{Acknowledgements}

This research was funded by DANIDA (Denmark; project 91006) and supported by NERC (UK) within a New Investigators' Competition award (NE/D000157/1). Isotopic analyses were carried out at the NERC Isotope Geosciences Laboratory under award IP/884/1105. Fieldwork in Uganda was supported by the Department of Geology at Makerere University, and Makerere University Biological Field Station. We thank Mr. Abdullah Mangalji for his hospitality in allowing access to Lake Kasenda; Jonathon St. Hill Cox and Menno Bouma for help in the field; Uganda National Council for Science and Technology (permit EC482), Uganda Wildlife Authority and the Office of the President for fieldwork permission; Lauren \& Colin Chapman, 
Dirk Verschuren and the late Henry Osmaston for logistical help. We thank Christine Cocquyt (National Botanical Gardens, Belgium) for valuable discussion on diatom taxonomy and ecology, and David Taylor and an anonymous reviewer for many helpful and stimulating comments, all of which have improved the paper. 


\section{References}

Appleby, P. G., 2001. Chronostratigraphic techniques in recent sediments. In (W. M. Last, and J. P. Smol, Eds.), Tracking Environmental Change Using Lake Sediments - Volume 1: Basin Analysis, Coring, and Chronological Techniques. Developments in

Paleoenvironmental Research. Springer, New York. pp. 171-203.

Atlas of Uganda, 1962. Government Printer, Entebbe.

Battarbee, R. W., and Kneen, M. J., 1982. The use of electronically counted microspheres in absolute diatom analysis. Limnology and Oceanography 27, 184-188.

Bennike, O., and Wiberg-Larsen, P., 2002. Seed-like hydroptilid larval cases (Insecta : Trichoptera) from Holocene freshwater deposits. Journal of Paleolimnology 27, 275-278.

Bessems, I., 2007. Late-Holocene climate reconstruction in equatorial East Africa: sedimentology and stable-isotope geochemistry of lake deposits. Unpublished $\mathrm{PhD}$ thesis., University of Ghent.

Bessems, I., Verschuren, D., Russell, J. M., Hus, J., Mees, F., and Cumming, B. F., 2008. Palaeolimnological evidence for widespread late 18th century drought across equatorial East Africa. Palaeogeography, Palaeoclimatology, Palaeoecology 259, 107-120.

Boutton, T. W., Archer, S. R., and Midwood, A. J., 1999. Stable isotopes in ecosystem science: Structure, function and dynamics of a subtropical Savanna. Rapid Communications in Mass Spectrometry 13, 1263-1277.

Bradshaw, E. G., Anderson, N. J., Jensen, J. P., and Jeppesen, E., 2002. Phosphorus dynamics in Danish lakes and the implications for diatom ecology and palaeoecology. Freshwater Biology 47, 1963-1975.

Cocquyt, C., 1998. Diatoms from the northern basin of Lake Tanganyika. J. Cramer, Berlin.

Cohen, A. S., Stone, J. R., Beuning, K. R. M., Park, L. E., Reinthal, P. N., Dettman, D., Scholz, C. A., Johnson, T. C., King, J. W., Talbot, M. R., Brown, E. T., and Ivory, S. J., 2007. Ecological consequences of early Late Pleistocene megadroughts in tropical Africa. Proceedings of the National Academy of Sciences 104, 16422-16427.

Dean, W. E., Jr., 1974. Determination of carbonate and organic matter in calcareous sediments and sedimentary rocks by loss-on-ignition: comparison with other methods. Journal of Sedimentary Petrology 44, 242-248. 
deMenocal, P. B., 2001. Cultural responses to climate change during the late Holocene. Science 292, 667-673.

Dong, X., Bennion, H., Battarbee, R. W., Yang, X., Yang, H., and Liu, E., 2008. Tracking eutrophication in Taihu Lake using the diatom record: potential and problems. Journal of Paleolimnology 40, 413-429.

Eggermont, H., Heiri, O., and Verschuren, D., 2006. Fossil Chironomidae (Insecta : Diptera) as quantitative indicators of past salinity in African lakes. Quaternary Science Reviews 25, 1966-1994.

Eggermont, H., and Verschuren, D., 2004a. Sub-fossil Chironomidae from East Africa. 1. Tanypodinae and Orthocladiinae. Journal of Paleolimnology 32, 383-412.

Eggermont, H., and Verschuren, D., 2004b. Sub-fossil Chironomidae from East Africa. 2. Chironominae (Chironomini and Tanytarsini). Journal of Paleolimnology 32, 413-455.

Fritz, S. C., 2004. In (R. W. Battarbee, C. E. Stickley, and F. Gasse, Eds.), Past climate variability through Europe and Africa. Developments in Paleoenvironmental Research. Elsevier, Dordrecht.

Fritz, S. C., 2008. Deciphering climatic history from lake sediments. Journal of Paleolimnology $39,5-16$.

Fritz, S. C., Juggins, S., and Battarbee, R. W., 1993. Diatom assemblages and ionic characterization of lakes of the northern Great Plains, North America: a tool for reconstructing past salinity and climate fluctuations. Canadian Journal of Fisheries Aquatic Sciences 50, 1844-1856.

Gasse, F., 1986. East African diatoms: taxonomy, ecological distribution. J. Cramer, Berlin.

Gasse, F., Juggins, S., and Khelifa, L. B., 1995. Diatom-based transfer functions for inferring past hydrochemical characteristics of African lakes. Palaeogeography, Palaeoclimatology, Palaeoecology 117, 31-54.

Germain, H., 1981. Flore des diatomées eaux douces et saumâtres. Société Nouvelle des Éditions Boubée, Paris.

Grimm, E. C., 1987. CONISS: A Fortran 77 program for stratigraphically constrained cluster analysis by the method of incremental sum of squares. Computer and Geosciences 13, 1335. 
Haberle, S. G., and David, B., 2004. Climates of change: human dimensions of Holocene environmental change in low latitudes of the PEPII transect. Quaternary International 118-119, 165-179.

Hill, M. O., 1973. Diversity and evenness: a unifying notation and its consequences. Ecology 54, 427-432.

Hofmann, W., 1986. Chironomid analysis. In (B. E. Berglund, Ed.), Handbook of Holocene Palaeoecology and Palaeohydrology. John Wiley \& Sons, Chichester. pp. 715-727.

Hunt, C. O., Gilbertson, D. D., and El-Rishi, H. A., 2007. An 8000-year history of landscape, climate, and copper exploitation in the Middle East: the Wadi Faynan and the Wadi Dana National Reserve in southern Jordan. Journal of Archaeological Science 34, 1306-1338.

Juggins, S., 2003. C2 User guide. Software for ecological and palaeoecological data analysis and visualisation (C2 version 1.4.3, build 1). University of Newcastle, Newcastle upon Tyne.

Kilham, P., Kilham, S. S., and Hecky, R. E., 1986. Hypothesized resource relationships among African planktonic diatoms. Limnology and Oceanography 31, 1169-1181.

Krammer, K., and Lange-Bertalot, H., 1986. Bacillariophyceae. 1: Teil: Naviculaceae. In (H. Ettl, G. Gärtner, J. Gerloff, H. Heynig, and D. Mollenhauer, Eds.), Süsswasserflora von Mitteleuropa, Band 2/1. Gustav Fischer Verlag, Stuttgart, New York. pp. 876.

Krammer, K., and Lange-Bertalot, H., 1988. Bacillariophyceae. 2: Teil: Bacillariaceae, Epithemiaceae, Surirellaceae. In (H. Ettl, G. Gärtner, J. Gerloff, H. Heynig, and D. Mollenhauer, Eds.), Süsswasserflora von Mitteleuropa, Band 2/2. Gustav Fischer Verlag, Stuttgart, New York. pp. 596.

Krammer, K., and Lange-Bertalot, H., 1991a. Bacillariophyceae. 3: Teil: Centrales, Fragilariaceae, Eunotiaceae. In (H. Ettl, G. Gärtner, J. Gerloff, H. Heynig, and D. Mollenhauer, Eds.), Süsswasserflora von Mitteleuropa, Band 2/3. Gustav Fischer Verlag, Stuttgart, Jena. pp. 576.

Krammer, K., and Lange-Bertalot, H., 1991b. Bacillariophyceae. 4: Teil: Achnanthaceae. In (H. Ettl, G. Gärtner, J. Gerloff, H. Heynig, and D. Mollenhauer, Eds.), Süsswasserflora von Mitteleuropa, Band 2/4. Gustav Fischer Verlag, Stuttgart, Jena. pp. 437.

Lamb, A. L., Leng, M. J., Lamb, H. F., and Mohammed, M. U., 2004. Holocene climate and vegetation change in the Main Ethiopian Rift Valley, inferred from the composition $(\mathrm{C} / \mathrm{N}$ and $\mathrm{d}^{13} \mathrm{C}$ ) of lacustrine organic matter. Quaternary Science Reviews 23, 881-891. 
Lamb, H. F., Bates, C. R., Coombes, P. V., Marshall, M. H., Umer, M., Davies, S. J., and Dejen, E., 2007a. Late Pleistocene desiccation of Lake Tana, source of the Blue Nile. Quaternary Science Reviews 26, 287-299.

Lamb, H. F., Kebede, S., Leng, M. J., Ricketts, D., Telford, R. J., and Umer, M. U., 2002. Origin and isotopic composition of aragonite laminae in an Ethiopian crater lake. In (E. O.

Odada, and D. O. Olago, Eds.), The East African Great Lakes: Limnology, Palaeolimnology and Biodiversity. Advances in Global Change Research Series. Kluwer Academic Publishers. pp. 487-508.

Lamb, H. F., Leng, M. J., Telford, R. J., Ayenew, T., and Umer, M., 2007b. Oxygen and carbon isotope, composition of authigenic carbonate from an Ethiopian lake: a climate record of the last 2000 years. Holocene 17, 517-526.

Langdale-Brown, I., Osmaston, H. A., and Wilson, J. G., 1964. The vegetation of Uganda and its bearing on land-use. Uganda Government Printer, Entebbe.

Legesse, D., Gasse, F., Radakovitch, O., Vallet-Coulomb, C., Bonnefille, R., Verschuren, D., Gibert, E., and Barker, P., 2002. Environmental changes in a tropical lake (Lake Abiyata, Ethiopia) during recent centuries. Palaeogeography, Palaeoclimatology, Palaeoecology $187,233-258$.

Leng, M. J., and Marshall, J. D., 2004. Palaeoclimate interpretation of stable isotope data from lake sediment archives. Quaternary Science Reviews 23, 811-831.

Melack, J. M., 1978. Morphometric, physical and chemical features of the volcanic crater lakes of western Uganda. Archiv für Hydrobiologie 84, 430-453.

Meyers, P. A., and Teranes, J. L., 2001. Sediment organic matter. In (W. M. Last, and J. P. Smol, Eds.), Tracking environmental change using lake sediments. Volume 2: Physical and geochemical methods. Kluwer Academic Publishers, Dordrecht. pp. 239-269.

Mills, K., 2009. Ugandan Crater Lakes: Limnology, Palaeolimnology and Palaeoenvironmental history. Loughborough University.

Nicholson, S. E., 1986. The spatial coherence of African rainfall anomalies: interhemispheric connections. Journal of Climatology and Applied Meteorology 25, 1365-1381.

Nicholson, S. E., 1998. Historical fluctuations of Lake Victoria and other lakes in the northern rift valley of East Africa. In (J. T. Lehman, Ed.), Environmental change and response in East African lakes. Monographiae Biologicae. Kluwer, Dordrecht. pp. 7-35. 
Renberg, I., 1990. A procedure for preparing large sets of diatom slides from sediment cores. Journal of Paleolimnology 4, 87-90.

Renberg, I., 1991. The HON-Kajak sediment corer. Journal of Paleolimnology 6, 167-170.

Roberts, N., Stevenson, T., Davis, B., Cheddadi, R., Brewster, S., and Rosen, A., 2004. Holocene climate, environment and cultural change in the circum-Mediterranean region. In (R. W. Battarbee, F. Gasse, and C. E. Stickley, Eds.), Past climate variability through Europe and Africa. Developments in Paleoenvironmental Research. Elsevier, Dordrecht. pp. 343-362.

Robertshaw, P., and Taylor, D., 2000. Climate change and the rise of political complexity in western Uganda. The Journal of African History 41, 1-28.

Robertshaw, P., Taylor, D., Doyle, S., and Marchant, R., 2004. Famine, climate and crisis in western Uganda. In (R. W. Battarbee, F. Gasse, and C. E. Stickley, Eds.), Past climate variability through Europe and Africa. Developments in Paleoenvironmental Research. Elsevier, Dordrecht. pp. 535-550.

Russell, J. M., and Johnson, T. C., 2005. A high-resolution geochemical record from Lake Edward, Uganda Congo and the timing and causes of tropical African drought during the late Holocene. Quaternary Science Reviews 24, 1375-1389.

Russell, J. M., and Johnson, T. C., 2007. Little Ice Age drought in equatorial Africa: Intertropical Convergence Zone migrations and El Nino-Southern Oscillation variability. Geology 35, 21-24.

Russell, J. M., McCoy, S. J., Verschuren, D., Bessems, I., and Huang, Y., 2009. Human impacts, climate change, and aquatic ecosystem response during the past $2000 \mathrm{yr}$ at Lake Wandakara, Uganda. Quaternary Research 72, 315-324.

Russell, J. M., Verschuren, D., and Eggermont, H., 2007. Spatial complexity of 'Little Ice Age' climate in East Africa: sedimentary records from two crater lake basins in western Uganda. The Holocene 17, 183-193.

Ryner, M., Holmgren, K., and Taylor, D., 2008. A record of vegetation dynamics and lake level changes from Lake Emakat, northern Tanzania, during the last c. 1200 years. Journal of Paleolimnology 40, 583-601.

Ryves, D. B., Battarbee, R. W., Juggins, S., Fritz, S. C., and Anderson, N. J., 2006. Physical and chemical predictors of diatom dissolution in freshwater and saline lake sediments in North America and West Greenland. Limnology and Oceanography 51, 1355-1368. 
Ryves, D. B., Juggins, S., Fritz, S. C., and Battarbee, R. W., 2001. Experimental diatom dissolution and the quantification of microfossil preservation in sediments.

Palaeogeography, Palaeoclimatology, Palaeoecology 172, 99-113.

Ssemmanda, I., Ryves, D. B., Bennike, O., and Appleby, P. G., 2005. Vegetation history in west Uganda during the last 1200 years: a sediment-based reconstruction from two crater lakes. The Holocene 15, 119-132.

Stager, J. C., Cumming, B., and Meeker., L. D., 1997. A high-resolution 11,400-year diatom record from Lake Victoria, East Africa. Quaternary Research 47, 81-89.

Stager, J. C., and Mayewski, P. A., 1997. Abrupt early to mid-Holocene climatic transition registered at the equator and the poles. Science 276, 1834-1836.

Stager, J. C., Ryves, D. B., Cumming, B. F., Meeker, L. D., and Beer, J., 2005. Solar variability and the level of Lake Victoria, East Africa, during the last millenium. Journal of Paleolimnology 33, 243-251.

Street-Perrott, F. A., Barker, P. A., Swain, D. L., Ficken, K. J., Wooller, M. J., Olago, D. O., and Huang, Y., 2007. Late Quaternary changes in ecosystems and carbon cycling on Mt. Kenya, East Africa: a landscape-ecological perspective based on multi-proxy lakesediment influxes. Quaternary Science Reviews 26, 1838-1860.

Talbot, M. R., and Livingstone, D. A., 1989. Hydrogen Index and Carbon Isotopes of Lacustrine Organic-Matter as Lake Level Indicators. Palaeogeography Palaeoclimatology Palaeoecology 70, 121-137.

Talling, J. F., 1966. The annual cycle of stratification and phytoplankton growth in Lake Victoria (East Africa). Internationale Revue der gesamten Hydrobiologie 51, 545-621.

Taylor, D., Marchant, R. A., and Robertshaw, P., 1999. A sediment-based history of medium altitude forest in central Africa: a record from Kabata Swamp, Ndale volcanic field, Uganda. Journal of Ecology 87, 303-315.

Taylor, D., Robertshaw, P., and Marchant, R. A., 2000. Environmental change and politicaleconomic upheaval in precolonial western Uganda. The Holocene 10, 527-536.

ter Braak, C. J. F., 1995. Ordination. In (R. H. G. Jongman, C. J. F. ter Braak, and O. F. R. van Tongeren, Eds.), Data analysis in community and landscape ecology. Cambridge University Press, Cambridge, England. pp. 91-173. 
ter Braak, C. J. F., and Šmilauer, P., 2002. Canoco for Windows 4.5. Centre for Biometry, Wageningen.

Tierney, J. E., Mayes, M. T., Meyer, N., Johnson, C., Swarzenski, P. W., Cohen, A. S., and Russell, J. M., 2010. Late-twentieth-century warming in Lake Tanganyika unprecedented since AD 500. Nature Geoscience 3, 422-425.

Tinner, W., Lotter, A., Ammann, B., Conedera, M., Hubschmid, P., van Leeuwen, J. F. N., and Wehrli, M., 2003. Climatic change and contemporaneous land-use phases north and south of the Alps 2300 BC to 800 AD. Quaternary Science Reviews 22, 1447-1460.

Tonk, L., Bosch, K., Visser, P. M., and Huisman, J., 2007. Salt tolerance of the harmful cyanobacterium Microcystis aeruginosa. Aquatic Microbial Ecology 46, 117-123.

Verschuren, D., 1997. Taxonomy and ecology of subfossil Chironomidae (Insecta, Diptera) from Rift Valley lakes in central Kenya. Arch. Hydrobiol./Suppl. (Monographic Studies) 4, 467-512.

Verschuren, D., Laird, K. R., and Cumming, B. F., 2000. Rainfall and drought in equatorial east Africa during the past 1,100 years. Nature 403, 410-414.

Wooller, M. J., Street-Perrott, F. A., and Agnew, A. D. Q., 2000. Late Quaternary fires and grassland palaeoecology of Mount Kenya, East Africa: evidence from charred grass cuticles in lake sediments. Palaeogeography, Palaeoclimatology, Palaeoecology 164, 223 246. 


\section{Figure Captions - Ryves et al.}

Figure 1. Location map of sites. (a) Key features of equatorial eastern Africa, including the rift valley system and associated lakes. Three letter country codes are given. Country borders are shown as dashed lines; solid black lines indicate major fracture zones of the rift valley system. (b) Detail showing the location of the northern crater lake region, and other sites mentioned in the text in western Uganda. Filled circles are lake sites ( $1=$ Kibengo, $2=$ Kitagata, $3=$ Chibwera, all on the rift floor $)$. White circles are archaeological sites mentioned in the text. Note that the archaeological site Kibengo (near Lake Albert) is further to the north than Lake Kibengo. (c) Location of Lakes Kasenda and Wandakara within the Kasenda lake cluster. NP boundary = National Park boundary .

Figure 2. Diatom taxa found in Lake Wandakara $>3 \%$ relative abundance in any sample arranged according to salinity optima (Gasse et al., 1995), on a calibrated age scale (years AD), with dissolution assessment (F index), diatom concentration, and sample diversity (Hill's $\mathrm{N}_{2}$ ). The results of Detrended Correspondence Analysis (DCA) axes 1 and 2 are plotted in conjunction with the diatom-inferred (DI) conductivity ( $\mu \mathrm{S} \mathrm{cm}^{-1}$ with RMSEP error bars) using a Ugandan crater lake dataset (K. Mills \& D. Ryves, unpublished data), with \% of fossil data included in the model. Current surface conductivity (from field measurements in 2000) is indicated. Zones were defined according to CONISS.

Figure 3. Diatom taxa found in Lake Kasenda $>3 \%$ relative abundance in any sample arranged according to salinity optima (Gasse et al., 1995), on a calibrated age scale (years AD), with dissolution assessment ( $\mathbf{F}$ index), diatom concentration, and sample diversity (Hill's $\mathrm{N}_{2}$ ). The results of Detrended Correspondence Analysis (DCA) axes 1 and 2 are plotted in conjunction with the diatom-inferred (DI) conductivity $\left(\mu \mathrm{S} \mathrm{cm}^{-1}\right.$ with RMSEP error bars) using a Ugandan crater lake dataset (K. Mills \& D. Ryves, unpublished data), with $\%$ of fossil data included in the model. Current surface conductivity (from field measurements in 2000) is indicated. Zones were defined according to CONISS.

Figure 4. Chironomid taxa (as percentage data) from Lake Wandakara sediments are displayed alongside the number of head capsules counted, Hill's $\mathrm{N}_{2}$ diversity index, 
DCA axis 1 sample scores and WA-inferred salinity (without deshrinking; Eggermont et al., 2006). Taxa are ordered according to WA optimum from Eggermont et al. (2006), given in $\mu \mathrm{S} \mathrm{cm}^{-1}$ after taxon name. Taxonomy follows Eggermont et al. (2004a, 2004b) except where indicated (following Verschuren, 1997).

Figure 5. Limnic faunal macrofossils from (a) Lake Wandakara and (b) Lake Kasenda. Values are given as accumulation rates per $\mathrm{cm}^{2}$ per yr, together with sample PCA axis 1 scores (standardised PCA with square-root flux data).

Figure 6. Summary diagram of physical and biological data from (a) Lake Wandakara, including bulk $\mathrm{C} / \mathrm{N}$ and $\delta^{13} \mathrm{C}_{\mathrm{org}}$ and (b) Lake Kasenda, including bulk $\mathrm{C} / \mathrm{N}, \delta^{13} \mathrm{C}_{\mathrm{org}}, \delta^{13} \mathrm{C}_{\mathrm{carb}}$ and $\delta^{18} \mathrm{O}_{\text {carb. }}$. Physical data (bulk magnetic susceptibility, organic matter, carbonate content, residue), summary pollen curves and flux of charcoal >350 $\mu \mathrm{m}$ taken from Ssemmanda et al. (2005).

Figure 7. Comparison of regional records of lake level over the last 1200 years from western Uganda (a - e) and Lake Victoria (f), from geochemical, biological and stratigraphic proxies. Data series are plotted so that drier conditions (lower lake level) appear as troughs in the records. (a) Lake Kasenda diatom-inferred conductivity; (b) Lake Wandakara diatom-inferred conductivity; (c) Lake Kitagata magnetic susceptibility (Russell et al., 2007); (d) Lake Kibengo calcium carbonate content (Russell et al., 2007); (e) Lake Edward Mg:Ca \% ratio (Russell and Johnson, 2005); (f) Lake Victoria shallow water diatom \% abundance (Stager et al., 2005). For Kasenda and Wandakara, periods of shallow water inferred from palaeolimnological proxies are indicated, as well as other evidence of significant limnological change: $\mathrm{Aul}=$ Aulacoseira granulata events; $\mathrm{F} / \mathrm{w}$ peri $=$ occurrence of freshwater periphyton; $\mathrm{Cyc}=$ Cyclotella meneghiniana events; the inwash event identified at Wandakara is also indicated. AMS ${ }^{14} \mathrm{C}$ dates are indicated: $*=$ dates on paired terrestrial macrofossils (Ssemmanda et al., 2005); \# = date on mixed terrestrial macrofossils (Bessems, 2007). Shaded bars indicate arid intervals identified from Kasenda and Wandakara records. 


\section{A.}
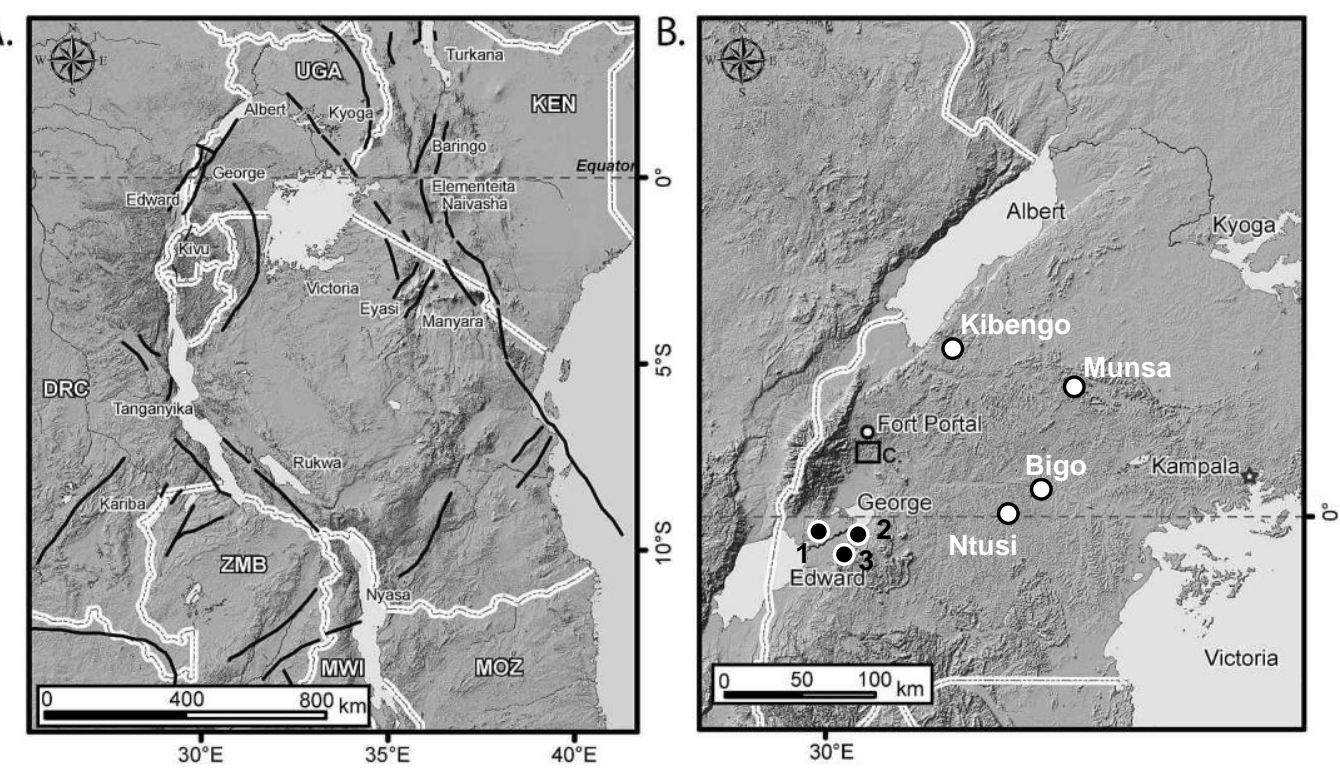

C.

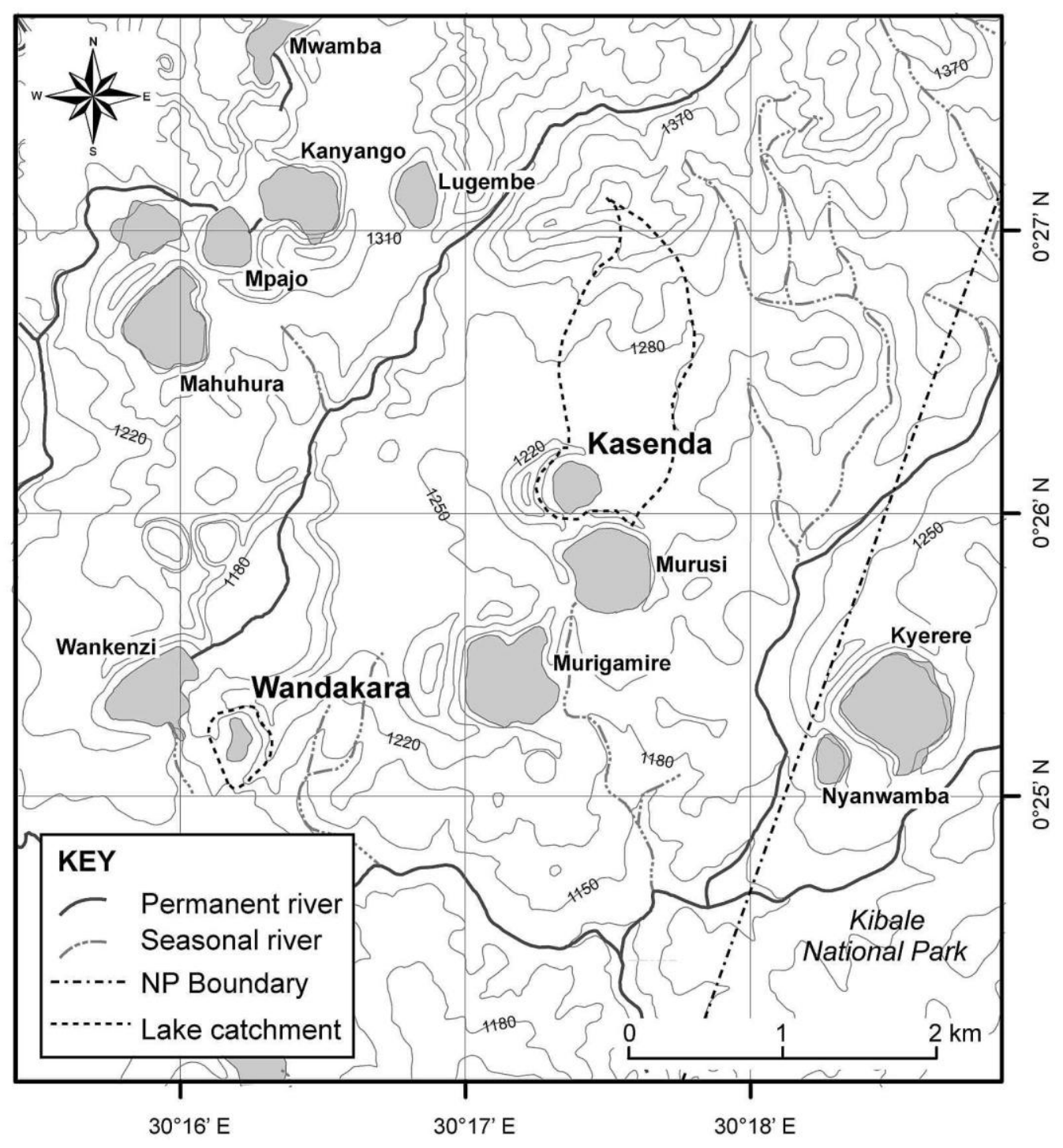




\section{Lake Wandakara}

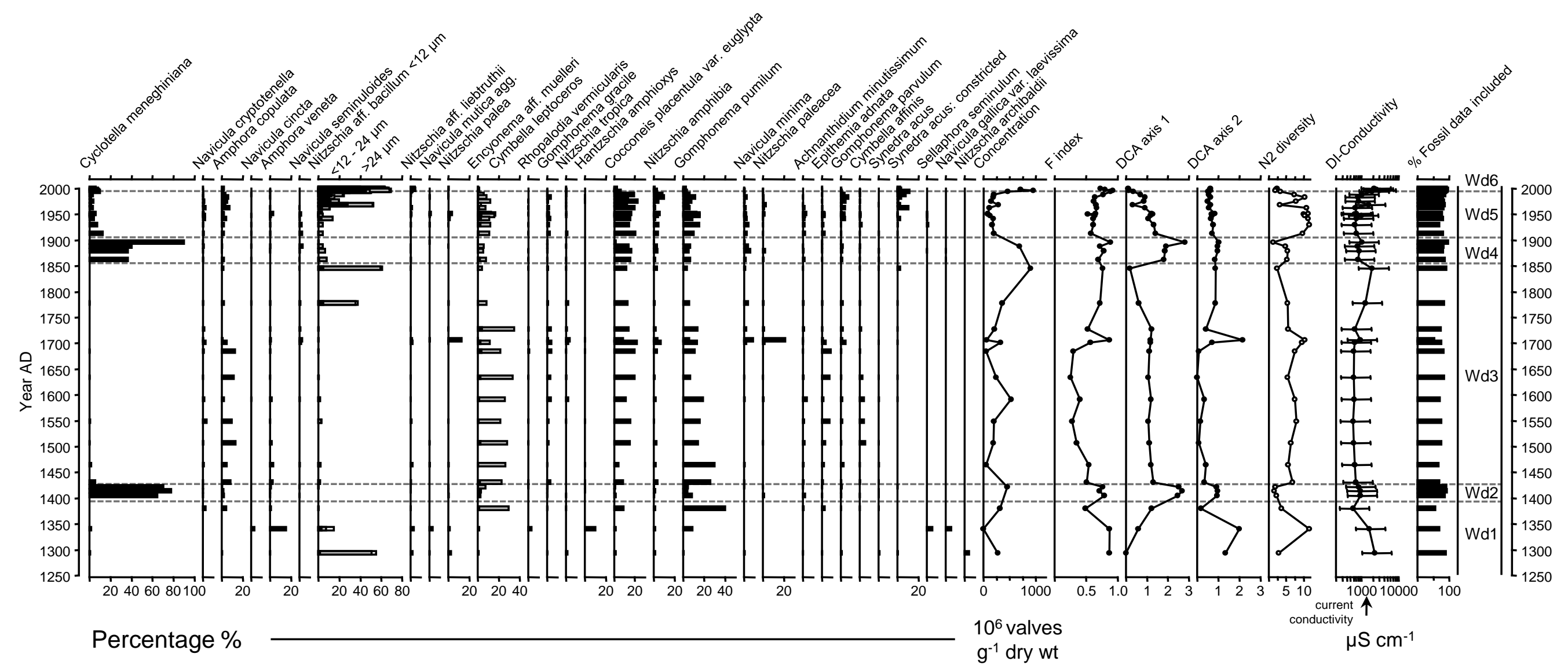


Ryves et al., Fig. 3

\section{Lake Kasenda}

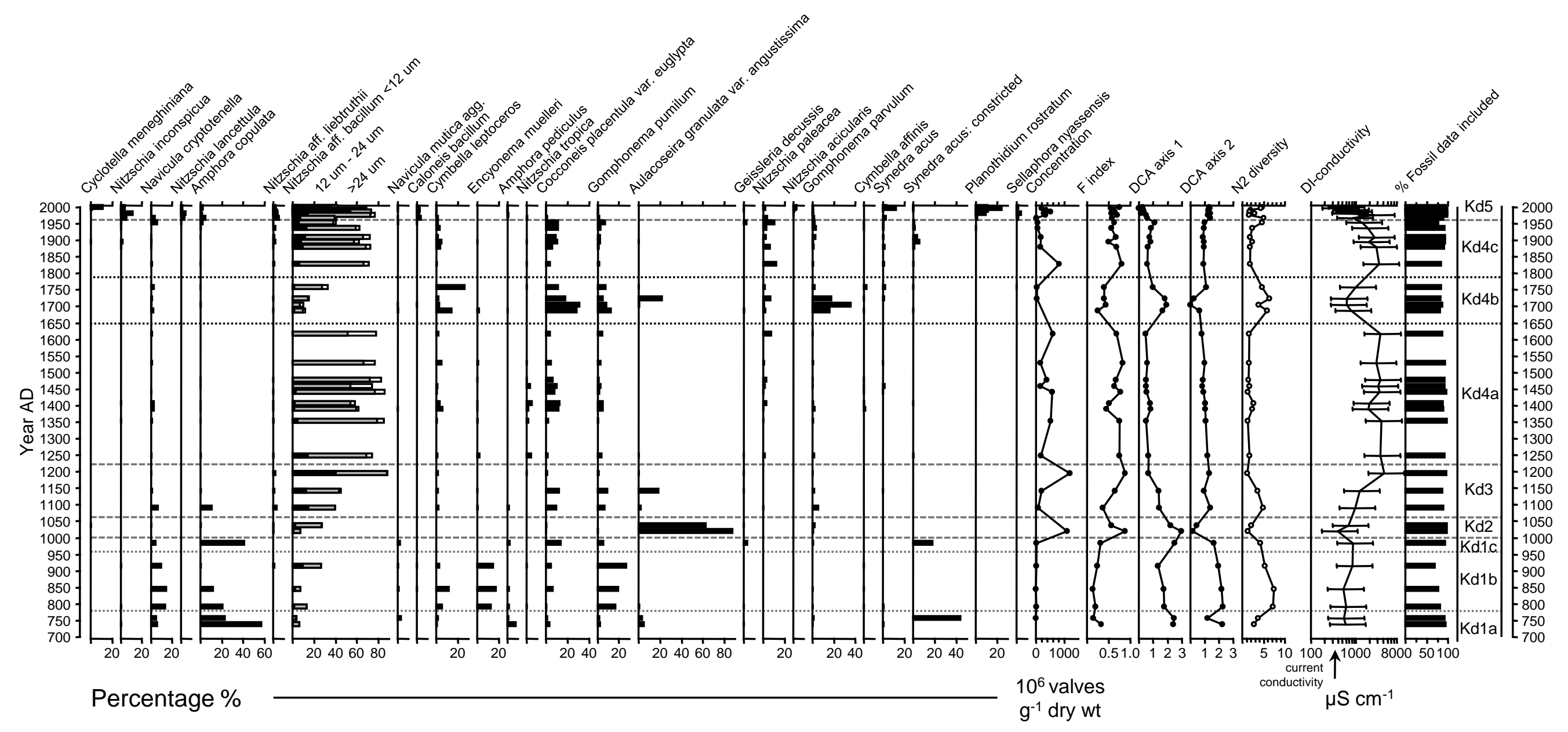




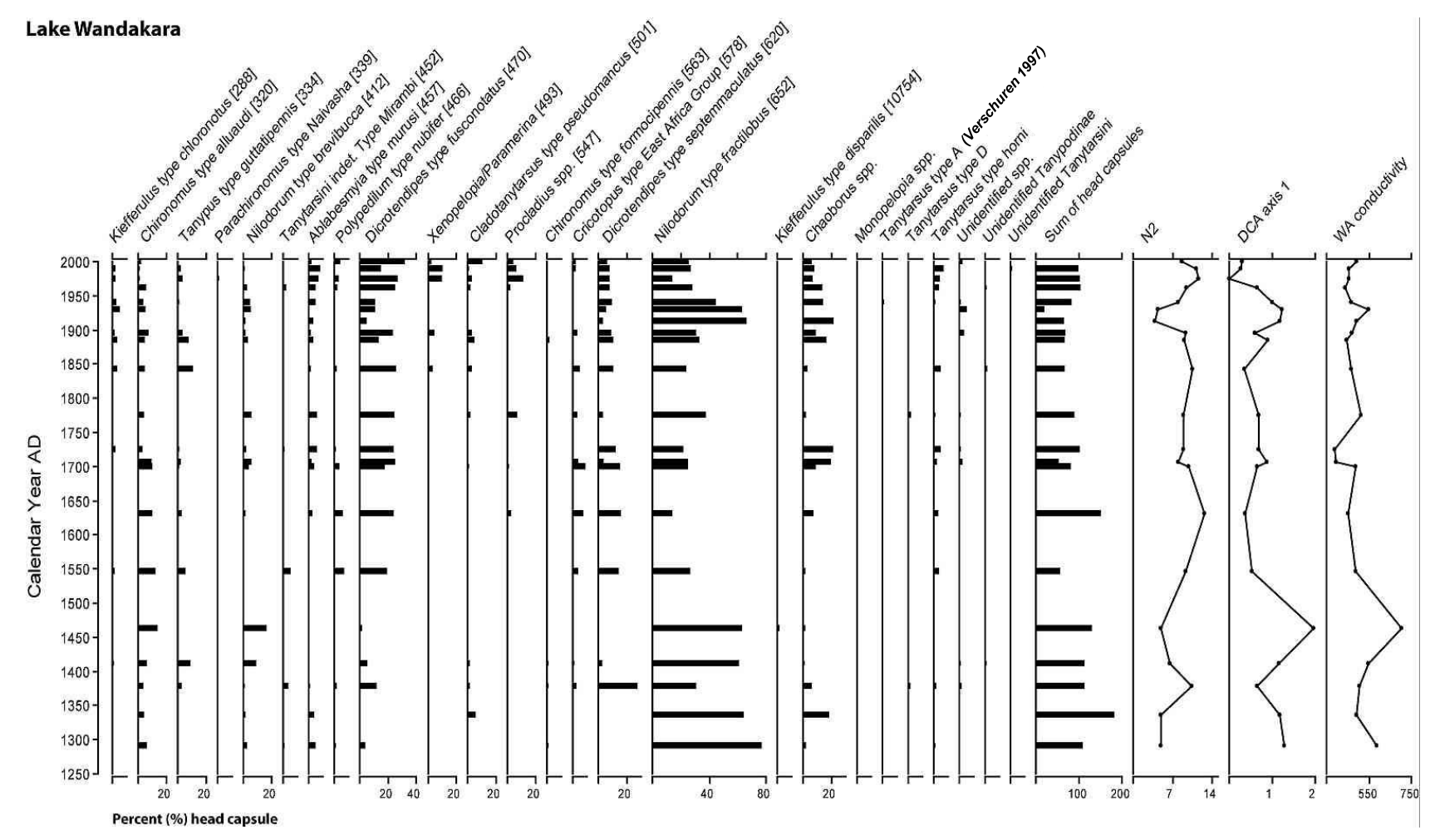




\section{a. Lake Wandakara}

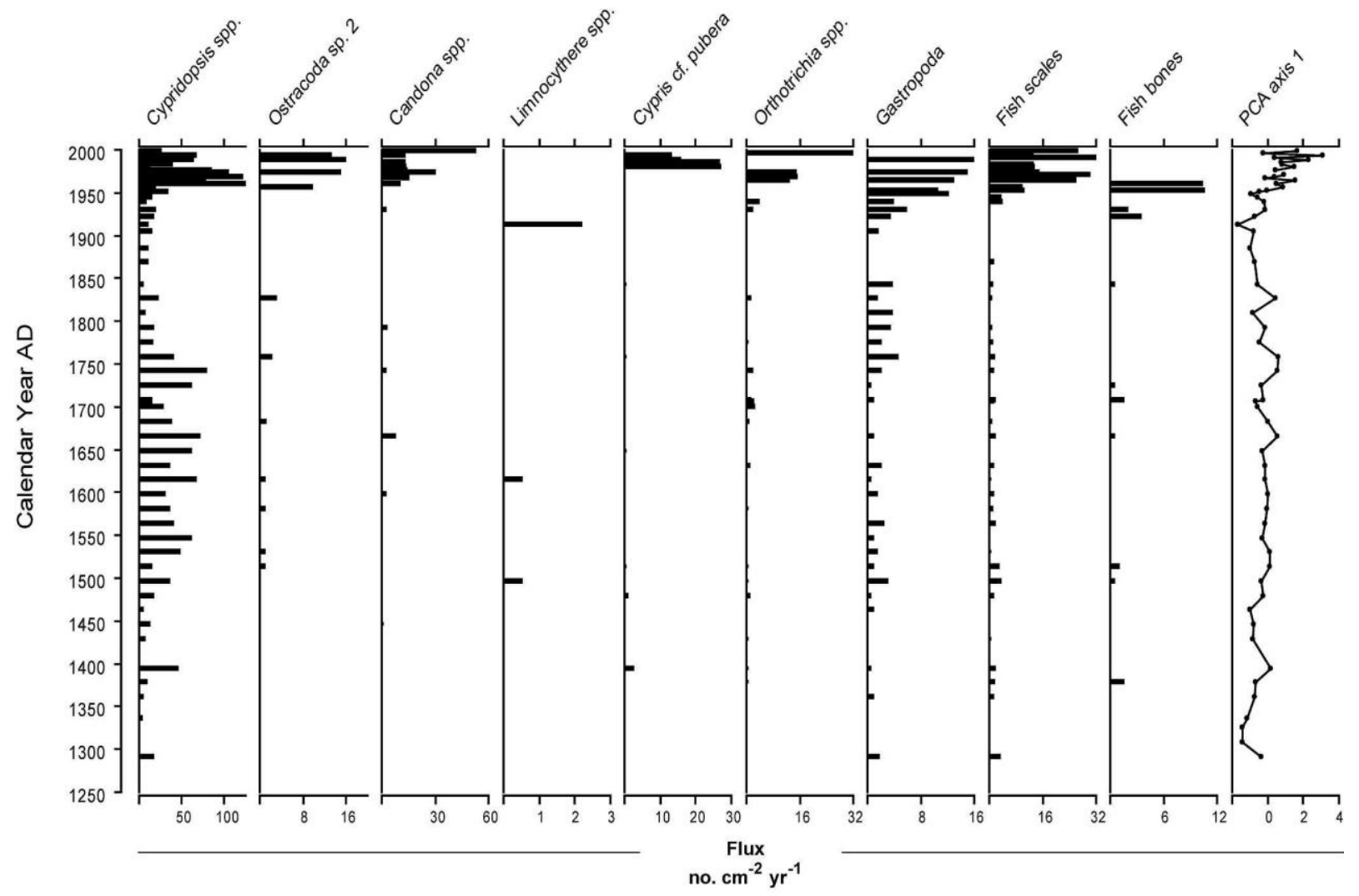

\section{b. Lake Kasenda}

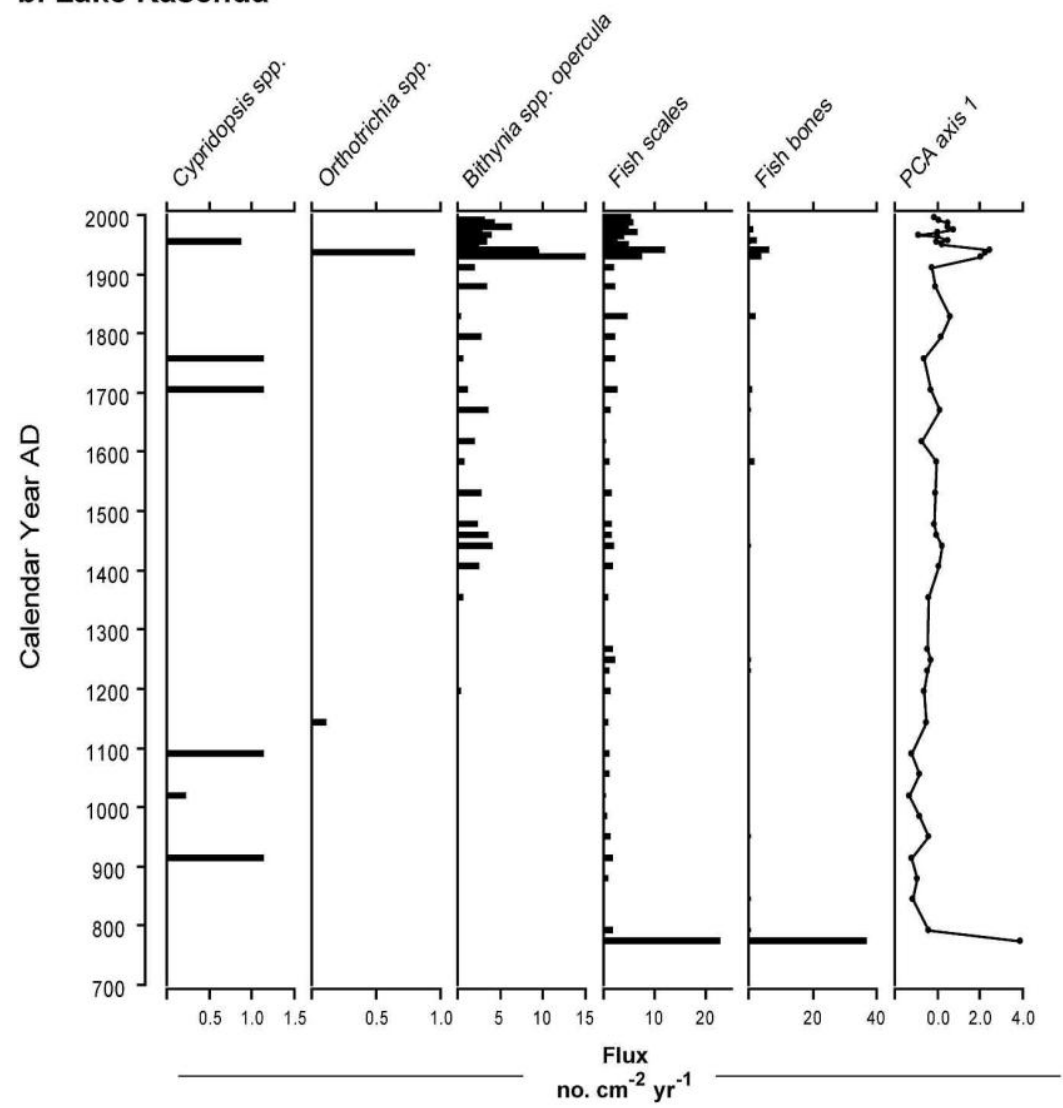




\section{a. Lake Wandakara}

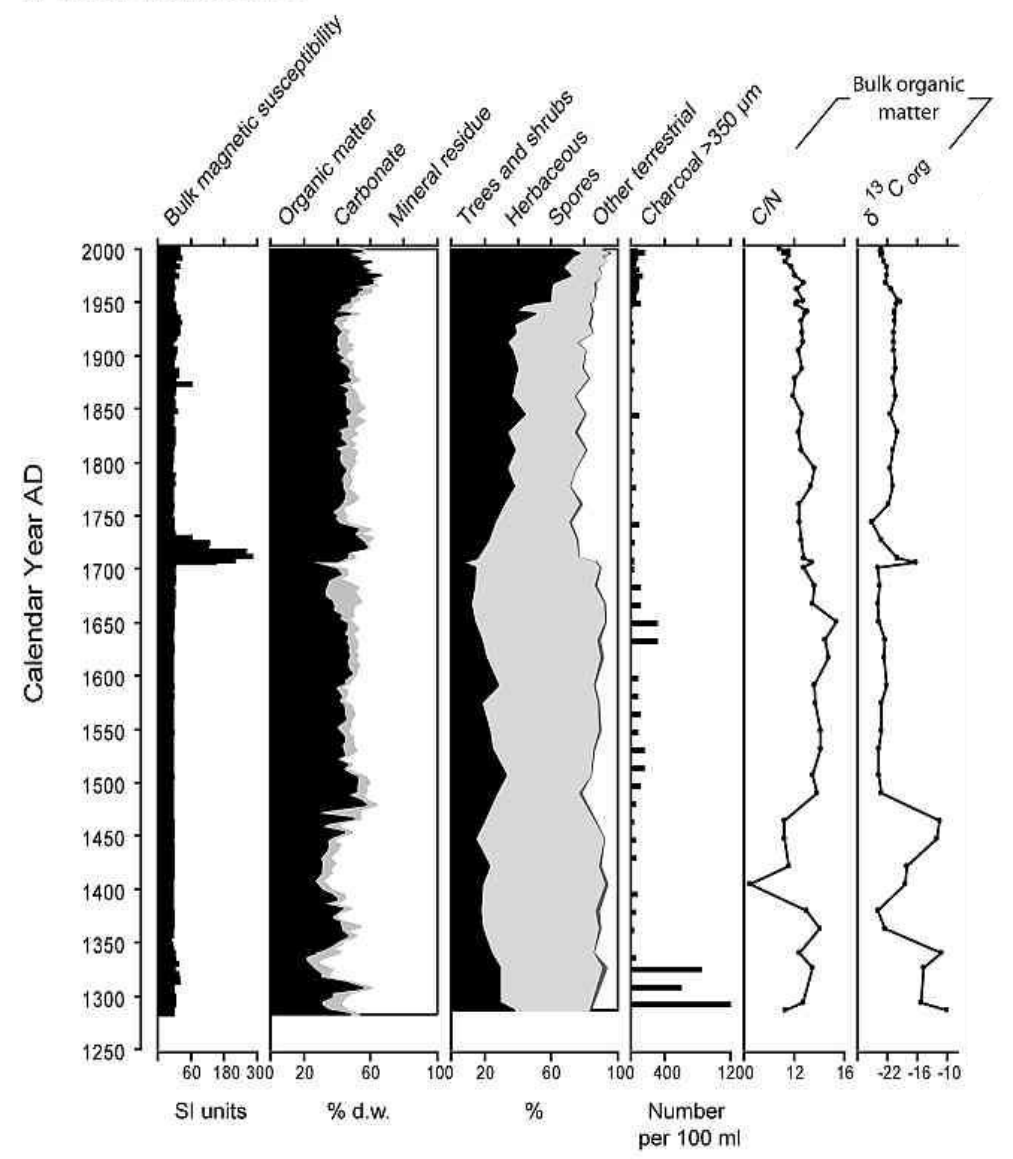

b. Lake Kasenda

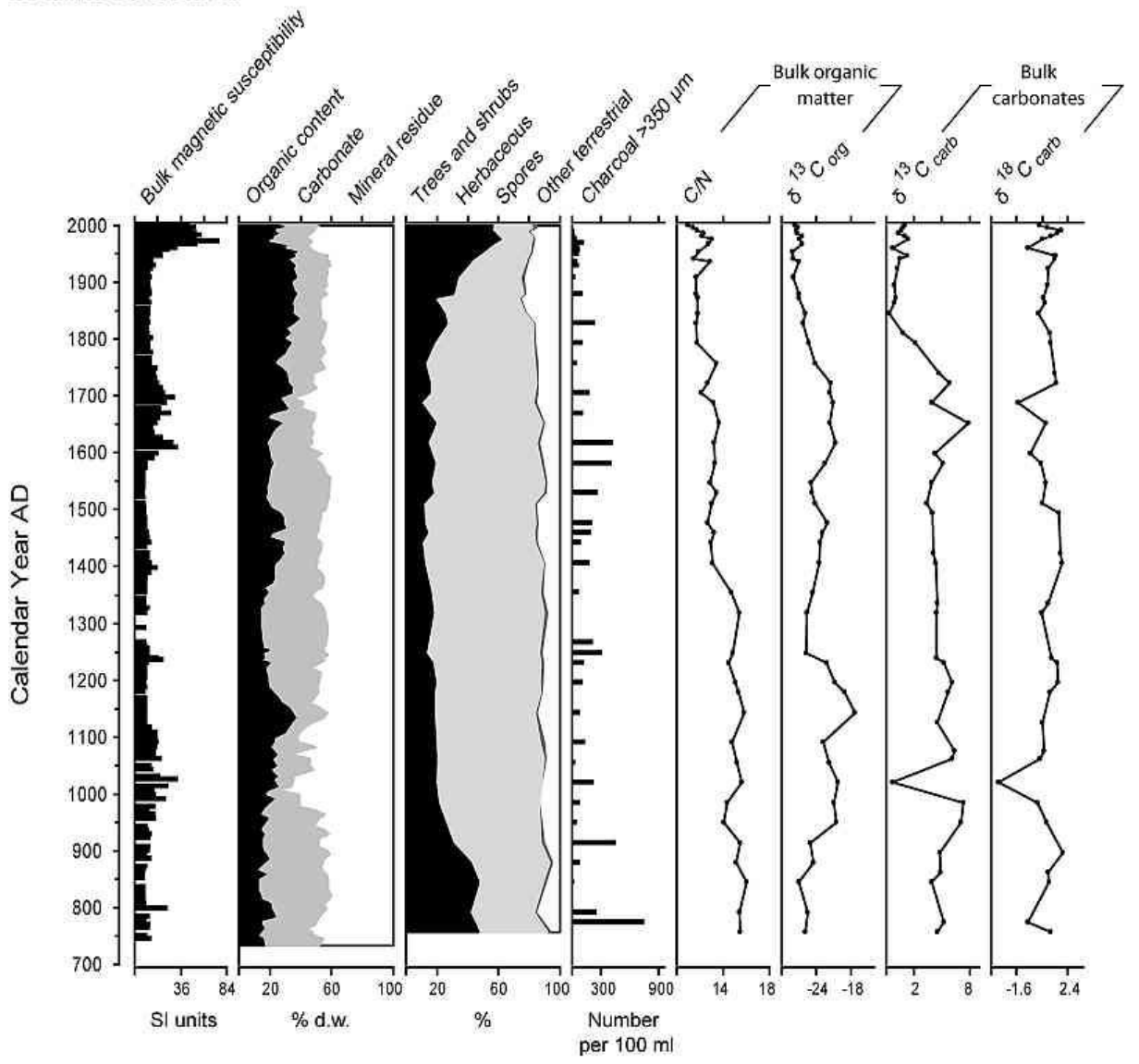


Year AD

$\begin{array}{llllllllllllll}700 & 800 & 900 & 1000 & 1100 & 1200 & 1300 & 1400 & 1500 & 1600 & 1700 & 1800 & 1900 & 2000\end{array}$

a. Kasenda DI-conductivity

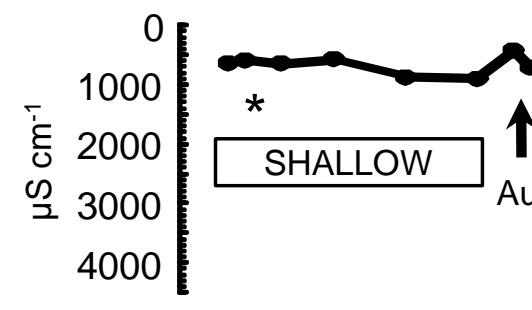

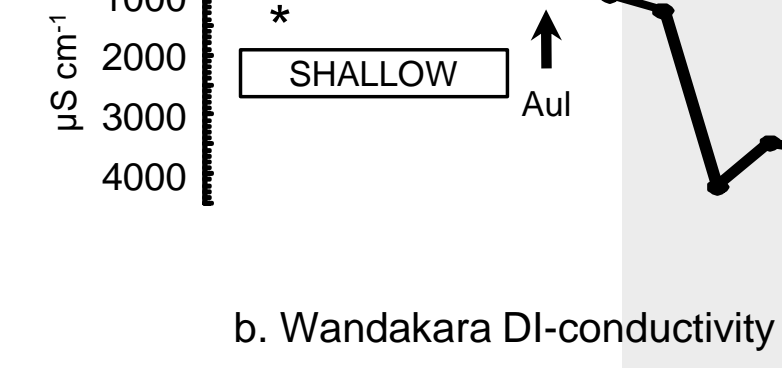
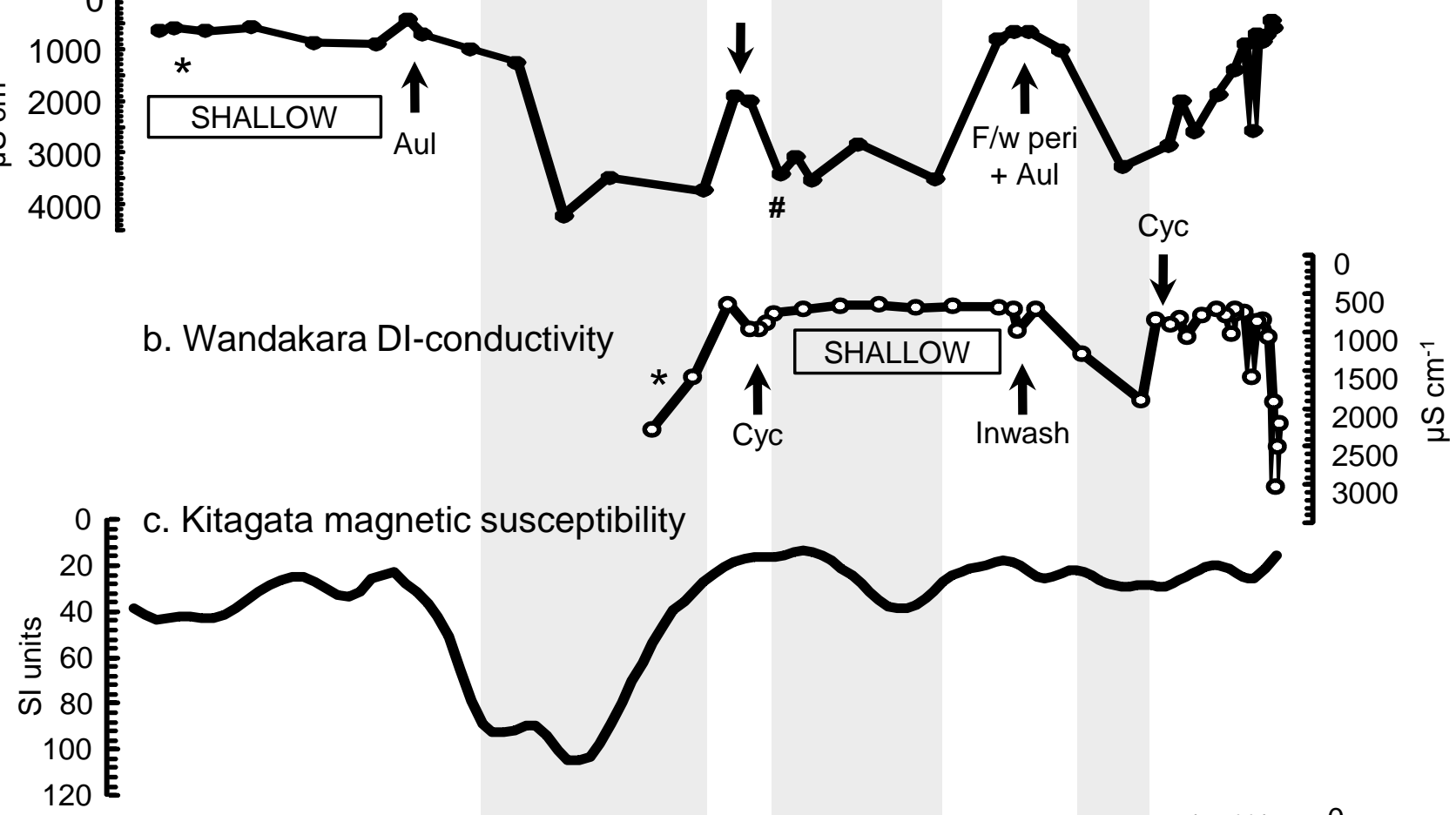

c. Kitagata magnetic susceptibility

F/w peri

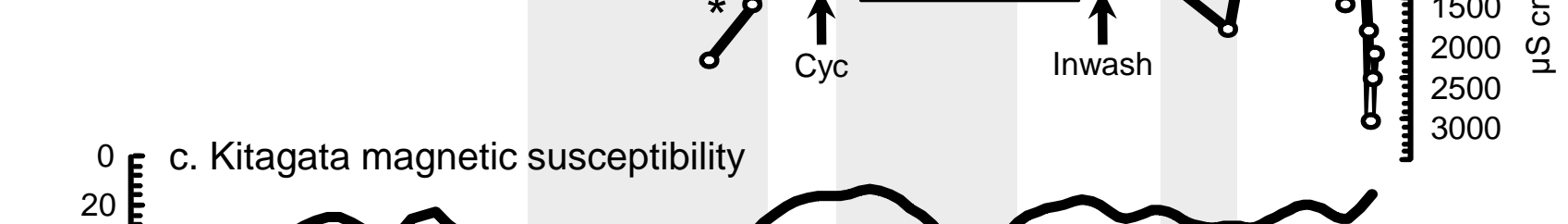

d. Kibengo $\mathrm{CO}_{3}$
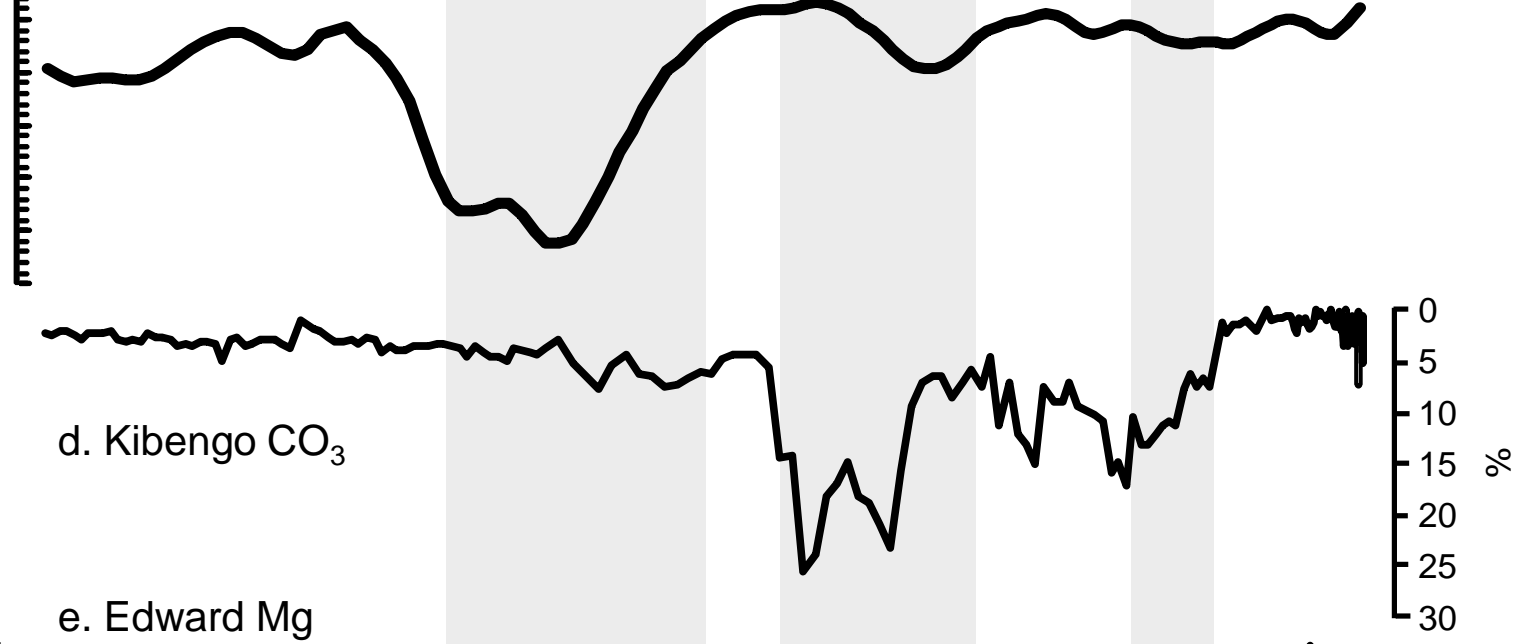

f. Victoria SWD

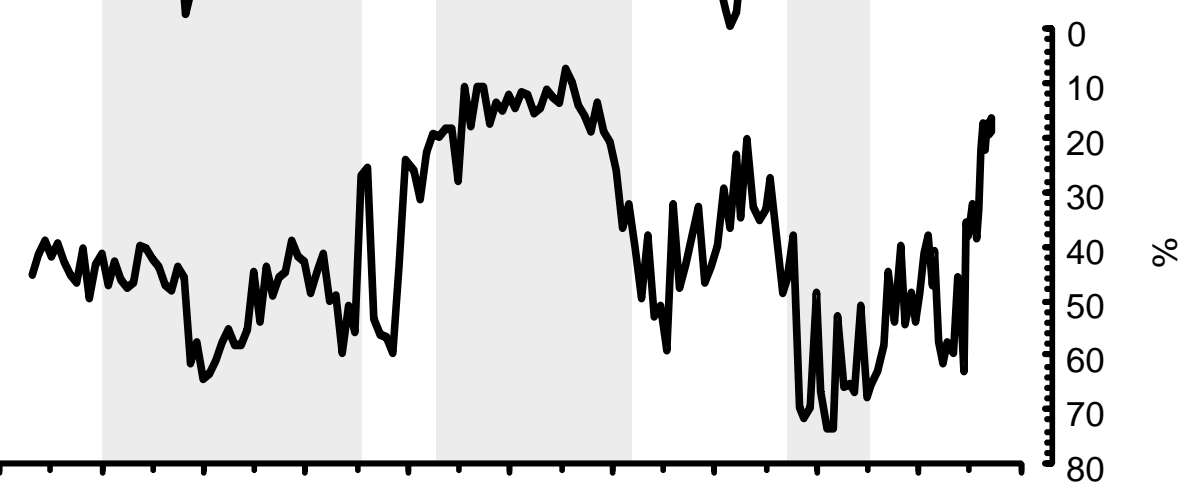

$\begin{array}{llllllllllllll}700 & 800 & 900 & 1000 & 1100 & 1200 & 1300 & 1400 & 1500 & 1600 & 1700 & 1800 & 1900 & 2000\end{array}$

Year $A D$ 